\title{
FROM THE INSTINCTUAL TO THE COSMIC: JUNG'S EXPLORATION OF COLOUR IN THE RED BOOK, 1915-1929/30
}

DIANE FINIELLO ZERVAS

PHANÊS • VOLUME $3 \cdot 2020$ • PP. 25-75

https://doi.org/10.32724/phanes.2020.Zervas 


\begin{abstract}
Jung wrote extensively about colour symbolism in his patients' dreams, paintings, and active imagination, beginning with his first mandala study in 1929, and continuing during the 1930s as he learned more about alchemy and Eastern esoteric texts. Students of Jung and Jungian analysts are already well acquainted with this material. The publication of The Red Book (2009), and Jung's visual works in The Art of C.G. Jung (2019), present new opportunities to study how Jung explored colour between 1915 and 1929. This paper will trace Jung's colour journey, concentrating on imagery that illustrates the instinctual and cosmic energies of the new god, the self and individuation. Jung's evolving colour symbolism demonstrates The Red Book's crucial role as an experimental medium, and confirms that Jung had developed a well-established colour hermeneutic by the 1920s.
\end{abstract}

\title{
KEY WORDS
}

colour, instinct, cosmos, new god, self, individuation, mandala, Goethe. 
$\mathrm{J}$ ung's most intense personal experiments with colour took place when he was engaged with The Red Book, the calligraphic version of Liber Novus (1913-1917) that he embellished with coloured initials, words, and images between 1915 and 1929. He employed watercolour and gouache pigments naturalistically to create the narrative episodes in some of the chapters of Liber Primus and Liber Secundus. In addition, he began to use them in a symbolic way for some of the imagery, and for the mandalas and paintings in the later sections of The Red Book that are unrelated to Liber Novus.

This paper will trace the evolving role of colour from the text of Liber Novus to the decoration of The Red Book, exploring how it complements and intensifies Jung's ability to evoke the instinctual and cosmic dimensions of his emerging new god and the self in visual forms, often before they were conceptualised into his written work. By closely observing Jung's experiments with colour symbolism during The Red Book period, it becomes possible to document their importance-albeit intentionally veiled - as a primary source of reference and ongoing reflection, when he subsequently investigated the emotional and symbolic meanings of colour in his patients' dreams, visions, and paintings, and related them to the works of medieval and modern mystics, and to the vast panoply of chromatic associations he mined from alchemical texts. Jung's exploration of colour in The Red Book is the hitherto unknown foundation for all his later hermeneutic colour studies, and provides a touchstone by which his awareness and use of contemporary artistic theories may be more thoroughly evaluated. ${ }^{1}$

\section{JUNG'S IDEAS ABOUT COLOURS BEFORE LIBER NOVUS AND THE RED BOOK, 1900-1913}

\section{Early Studies}

Fascinated by art from a young age, Jung explored books in his father's library, was taken to museums as a boy, and visited the Louvre

\footnotetext{
${ }^{1}$ Medea Hoch (2019) provides a useful overview of Jung's general concept of colour, relating it to the psychological aspects of colour in Goethe's 1810 Theory of Colour, Kandinsky's 1911 essay 'On The Spiritual in Art', the colour theories of the Dadaists, and the colour symbolism of medieval art and alchemy as potential sources.
} 
during his sojourn in Paris whilst attending the lectures of Janet in 1902-03, the British Museum in 1903, and the Armory Show when he was in New York in March 1913. He also sketched and painted. The Jung family archive includes works that he made between 1885-1908. Many of his pastels and watercolours reveal a propensity for strong colours, often applied more expressionistically than naturalistically. ${ }^{2}$

As a medical student, Jung was aware of contemporary research on the psychological effects of colour. At the beginning of his inaugural dissertation, 'On the Psychology of So-Called Occult Phenomena', he cited experiments published by Guinon and Woltke in 1891, which documented the strikingly analogous associative and emotion-toned hallucinations that regularly occurred in a female patient who viewed glass panels tinted blue, red, and yellow during hysterical attacks (1902:\$22). ${ }^{3}$ Their investigations may also have influenced Jung's decision to include colour words among the lists used for his word association tests conducted between 1902-10 (1909:§§941-942).

In a subsequent section of his dissertation, Jung detailed the elaborate mystic system of world forces 'revealed' to his cousin Helene in March 1900. The diagram she asked him to draw consisted of seven concentric circles. The Good or Light forces, Magnesor, are aligned on the left horizontal axis of the circles, and the Dark Powers, Connesor, on the right one. Helene visualised Magnesor 'as a shining white or bluish vapour that developed when good spirits are near', and then 'solidified' into visible white figures. Conestor was 'a black fuming fluid' that arose when 'black' spirits appeared, and then materialised into black figures (1902:§§65-70). Significantly, her hallucinatory images emerged from the two coloured mediums she perceived, as had those reported by Guinon and Woltke's hysterical patients when viewing their world through tinted glass. Thus by 1902 Jung was already professionally aware of emotional and symbolic associations linked with red, yellow, blue, green, black and white.

Given his early interest in the psychological effects of colours, it is likely that Jung had also researched symbolic colour theories. He owned a copy of Frédéric Portal's 1837 treatise, Des Couleurs symboliques

\footnotetext{
${ }^{2}$ Sonu Shamdasani (Introduction, RB RE:9-10,33-34); Art: Cats. 8, 10, 12, 13, 16, 21. See Hoerni (2019:12-13), Fischer and Kaufmann (2019:20-21), for Jung's early influences and collection of art reproductions and paintings.

${ }^{3}$ Although Jung only mentioned one female patient, the colour-related responses he cited pertain to Guinon and Woltke's final conclusions, which summarise three patients' similar reactions when exposed to glass tinted red (evoking blood, wounds), yellow (sun, yellow clothing), various tones of blue (mother, sky) and green (grass, fields, dark water, loneliness, fear) (Guinon and Woltke 1891:353, 357, 361-262).
} 
(1837), but its date of purchase is unknown. Through patients and colleagues connected to the art world, he may have been aware of various contemporary colour theories before 1915 (LN RE:33-37; Shamdasani 2018; Hoch 2019:34-35).

\section{Goethe's Theory of Colours}

Jung was familiar with Goethe's influential Theory of Colours (1810), included in the poet's scientific writings. He cited Eckermann's Conversations with Goethe, which contain numerous discussions on Goethe's colour theories, in his dissertation, and quoted Goethe's description of his ability to produce waking 'dream pictures' - an important precursor of active imagination (1902:28, 143n, 183). Goethe had observed that 'particular colours excite particular states of feeling' (1840:\$762; Hoch 2019:33), a statement that later 19th century researchers set out to demonstrate, and Jung's investigations continued to confirm. ${ }^{4}$

Attempting to disprove Newtonian colour theory, Goethe had discovered that all colours arise from the elementary opposition of light and darkness. He first noticed this by observing the junction between a dark surface and a light surface through a prism: the colours only appeared at the junction. Therefore both light and dark were necessary to 'call forth the colours'. Seeking confirmation in nature, the Urphänomen - the darkness of the sky and light of the sun-Goethe found that the colour blue arose by looking at the darkness of outer space through the light of the atmosphere: the origin of blue is the lightening of dark that occurs when dark is seen through light. Similarly, he observed that the origin of red and yellow, the two other primary colours, could be discovered in the sun's changing colours. Overhead on a clear day, the sun is yellow; it darkens towards red as it moves closer to the horizon at sunset, and becomes whiter higher up in space as atmospheric thickness decreases. Therefore the origin of yellow and red is the darkening of light that occurs when light is observed through the atmosphere: light seen through dark.

\footnotetext{
${ }^{4}$ In his 1925 Introduction to Jungian Psychology seminar, Jung explained that he had asked a patient to 'try to express in color the inner condition of his mind' (1989a:109). Describing the four colours in the Tibetan Book of the Dead in his ETH seminar on mandalas in the East and West, and Shünyatā, Jung linked them to the four psychological functions, adding 'colours are feeling values' ([10 February 1939] 1959, 3:77-78), a view reiterated in Mysterium Coniunctionis: for patients using active imagination (and sometimes in dreams), 'colours are feeling values', and the appearance of colour signifies a shift from intellectual interest to emotional participation (1955:§333). See also Hoch (2019).
} 
Thus for Goethe, as he wrote in his Preface, colours are 'the deeds and sufferings' of light ('Die Farben sind Taten des Lichts, Taten und Leiden') (Goethe 1810:24). Although also attentive to colours' possible meanings, Goethe refrained from elaborating them, believing 'if our doctrine of colours finds favour, applications and allusions, allegorical, symbolical, and mystical, will not fail to be made, in conformity with the spirit of the age' (1810:§920:199; 1840:§920:193; italics added).

Goethe's ideas about the creation of colours from light and darkness would have resonated with Jung during the years he was working on Liber Novus and The Red Book, given his interest in the differentiation of psychological opposites, and their necessary role in generating the reconciling symbol, a subject he was both experiencing and exploring in Liber Novus, especially in Scrutinies (1917-18); in his Systema Mundi Totius (1916); his later mandalas and images in The Red Book and other visual works done between 1917-29; and his theoretical writings between 1914-21.5 Goethe's principle of systole and diastole, discussed frequently in his writings and mentioned twice in the Doctrine of Colour, is first cited by Jung in October 1916 in connection with introjection and projection, ${ }^{6}$ and subsequently in Psychological Types: the 'all-embracing principle of systole and diastole' is a metaphor for the 'natural life rhythm' of the individual's introverted and extraverted attitudes (1921b: §§4-6, 234, 340). ${ }^{7}$

\section{LIBER NOVUS}

Liber Novus originated as a series of dreams, visions, and episodes of active imagination that Jung recorded in his Black Books between 12 November 1913 and 19 April 1914. He began to compose it after the First World War broke out in August 1914, dividing the fantasies into chapters, adding commentaries and lyrical elaborations

\footnotetext{
5 Jung's statement 'To be quite accurate, human nature is just real; it has its light and its dark sides. The sum of all colours is grey-light on a dark background or dark on light', criticising Schiller's failure to include the ugly in his conception of the aesthetic, implies a knowledge of Goethe's colour theory. For Jung, as a result of his Liber Novus experiences, the new definition of beauty must include the light and the dark sides, the ugly and the beautiful (1921b:\$206). See Bishop on Jung, Schiller and the aesthetic (2008, 1:142); Shamdasani, 'Jung and Schiller', private seminar 9 September 2018. For the emergence of the reconciling symbol in Jung's visual works, see Zervas (2019a).

6 'Introjection and Projection', unpublished discussion of the Association for Analytical Psychology, October 1916 (Jung 1916a).

${ }^{7}$ Compare Jung's description with Goethe's: '[...] this is the life of nature, the eternal systole and diastole [...]': (1840:§38); see Bishop (2008,1:104-105).
} 
(Layer 2 in the modern edited text: Shamdasani RB RE:30-33).

The first part, originally untitled but implicitly Liber Primus, is introduced by a Prologue, 'The Way of What is to Come'. In the narrative that follows, Jung's 'I' refinds his soul, and explores her nature, and that of God. He is plunged into a 'Descent into Hell in the Future', with its disturbing images of a underground stream where a bloodied blond corpse and a black scarab float by, and a red sun glows in its depths, surrounded by thousands of black serpents. He then murders the German hero Siegfried, after which the 'Spirit of the Depths' makes a prophetic announcement of the 'Conception of the New God'. In the final section, the 'Mysterium', his 'I' encounters three important figures from the depths, the prophet Elijah and his blind daughter Salome, accompanied by a black serpent. He is instructed by them, and undergoes Christification: made to witness and suffer the crucifixion of Christ in himself.

In the much longer Liber Secundus, entitled 'The Images of the Erring', Jung's 'I' interacts with many other personifications from the depths, undergoes further initiatory experiences including a type of divine madness, encounters the magician Philemon, who teaches him about magic, and gives birth to the new god in himself.

Having completed the handwritten, typed and corrected typed drafts of Liber Novus in 1915, Jung decided to write his 'precious' experiences 'down in a "precious", that is to say costly, book and to paint the images that emerged through reliving it all' (Jung, 'Epilogue' 1959: RB RE:555). This is The Red Book, the calligraphic version of Liber Novus, which he began in the second half of 1915, and remained intensely engaged with over the next fifteen years. He transcribed the text in a version of German gothic script, and decorated it like an illuminated manuscript, initially employing expensive parchment sheets for Liber Primus, similar to works like the famous Swiss Codex Manesse, with which he was already familiar as a teenager (Art:63, Cat. 8). Possibly daunted by the challenges posed by painting on parchment, he commissioned a large red leather-bound book for Liber Secundus. ${ }^{8}$

Jung's decision to design The Red Book like a medieval manuscript was not merely aesthetic, however, but deeply symbolic. At the end of Liber Secundus, he had stated:

An opus is needed, that one can squander decades on, and do it out of necessity. I must catch up with a piece of

8 The physical aspects of The Red Book and its making have been discussed extensively by Mellick (2018, 2019). 
the Middle Ages - within myself. We have only finished

the Middle Ages of - others. I must begin early, in that

period when the hermits died out. (RB RE:457-458).

He alludes to the reasoning for this choice several years later, in Psychological Types, which included his exploration of the opposites in classical and medieval thought. In Chapter V, 'The Problem of Types in Poetry', Jung emphasised man's need to regress to an earlier mode of adaptation when confronted with an impossibly difficult task, and noted that Spitteler's attempt to return to classical forms in Prometheus and Epimetheus was unsuccessful, because 'the intervening centuries of Christianity, with their profound tides of spiritual experience, could not be denied'. It was now necessary to turn back to medieval form, as Goethe had done in Faust, with its depiction of the medieval magician who also preserved traces of primitive paganism, and, through his death and rebirth, becomes a reconciling symbol that includes the acceptance of evil and the redemption of the feminine (1923:231-234; 1921b: §§310317). This, of course, is what Jung had undertaken in Liber Novus, and emphasised by his choice of pictorial form for The Red Book.

In The Red Book, the pages of Liber Secundus are interspersed with images of visions and active imaginations that Jung experienced between 1916 and 1929. ${ }^{9}$ Some relate to themes included in Scrutinies, the complex third section that Jung planned to add to Liber Novus, which he began working on in late November 1917. Scrutinies incorporated Jung's fantasies between 19 April 1914 and 1 June 1916, The Seven Sermons to the Dead (1916), reworked sections, and further elaborations and commentaries (Shamdasani in RB RE:45-46).

\footnotetext{
${ }^{9}$ Between 26 January and October 1919, Jung kept the right (odd) pages of The Red Book blank for full-page paintings, and used the left (even) pages for his ongoing transcription of Liber Secundus, which in some cases post-dated the paintings opposite them (LN: odd pages between 103 and 119). He used both sides of the page for three paintings between November 1919 and 4 January 1920 (ibid:121-123), then reserved the odd pages for paintings between 25 January 1920-25 November 1922 (ibid: odd pages between 125-135). He did no full-page paintings in The Red Book between December 1922-December 1923, and only two-'Philemon' and 'The Anima as Altar' between January 1924 and 14 August 1925 (ibid: 154, 155). The final three full-page paintings in The Red Book date between 9 January 1927 (ibid:159) and 1929 (ibid:163, 169).
} 


\section{COLOUR IN THE TEXTS OF LIBER NOVUS AND THE RED BOOK}

\section{Liber Novus, 1913-1916}

An analysis of the text of Liber Novus confirms that colours appear often in the context of the narrative (Appendix, 1). The text includes many references to blood and bloody, in keeping with the turbulent historical period during which it was composed, and with the themes of sacrifice, death, and rebirth of a new god. Black, white, gold, green, blue, yellow and silver appear frequently. Significant images include black, white and iridescent serpents, a white bird, a black scarab and beetle, a red sun, the Red One, Jung's 'I' as a leafy green man and daimon, a black stranger (Death), a form dark as the earth and black as iron with gold eyes, and a blue shade or Christ (RB RE: 174, 194, 212, 216, 262, 263, 388, 413, 537, 551).

The text contains lyrical and symbolic evocations of colour. In 'The Murder of the Hero' (Liber Primus cap. vii), after Jung dreamed that his 'I' and an unknown companion had killed Siegfried, he had a second dream:

I saw a merry garden, in which forms walked clad in white silk, all covered in colored light, some reddish, the others blueish and greenish. (RB RE:162).

Jung interpreted it later, during his interviews with Aniela Jaffé for Memories, Dreams, Reflections:

[T]his dream expressed the idea that he was one thing and something else at the same time. The unconscious reached beyond one, like a saint's halo. The shadow was like the lightcolored sphere that surrounded the people. He thought this was a vision of the beyond, where men are complete. (Protocols:170; RB RE:162).

In 'The Anchorite' (Liber Secundus cap. iv), Jung's 'I' encounters a desert monk, and then spends the night in a cave. In the mantic section of Layer 2, he reflects on the solitary:

Dull from the sun and drunk from fermenting wines, you lie down in ancient graves, whose walls resound with many voices and many colors of a thousand solar years. (RB RE:249). 
After first meeting Philemon in 'The Magician' (Liber Secundus cap. xxi), Jung muses in Layer 2: 'you shimmered multi-colored and inextricable' (RB RE:408). Thus by 1915 he envisioned the beyond, the thousand solar years, and Philemon, as multicoloured, evoking the full colour spectrum. ${ }^{10}$

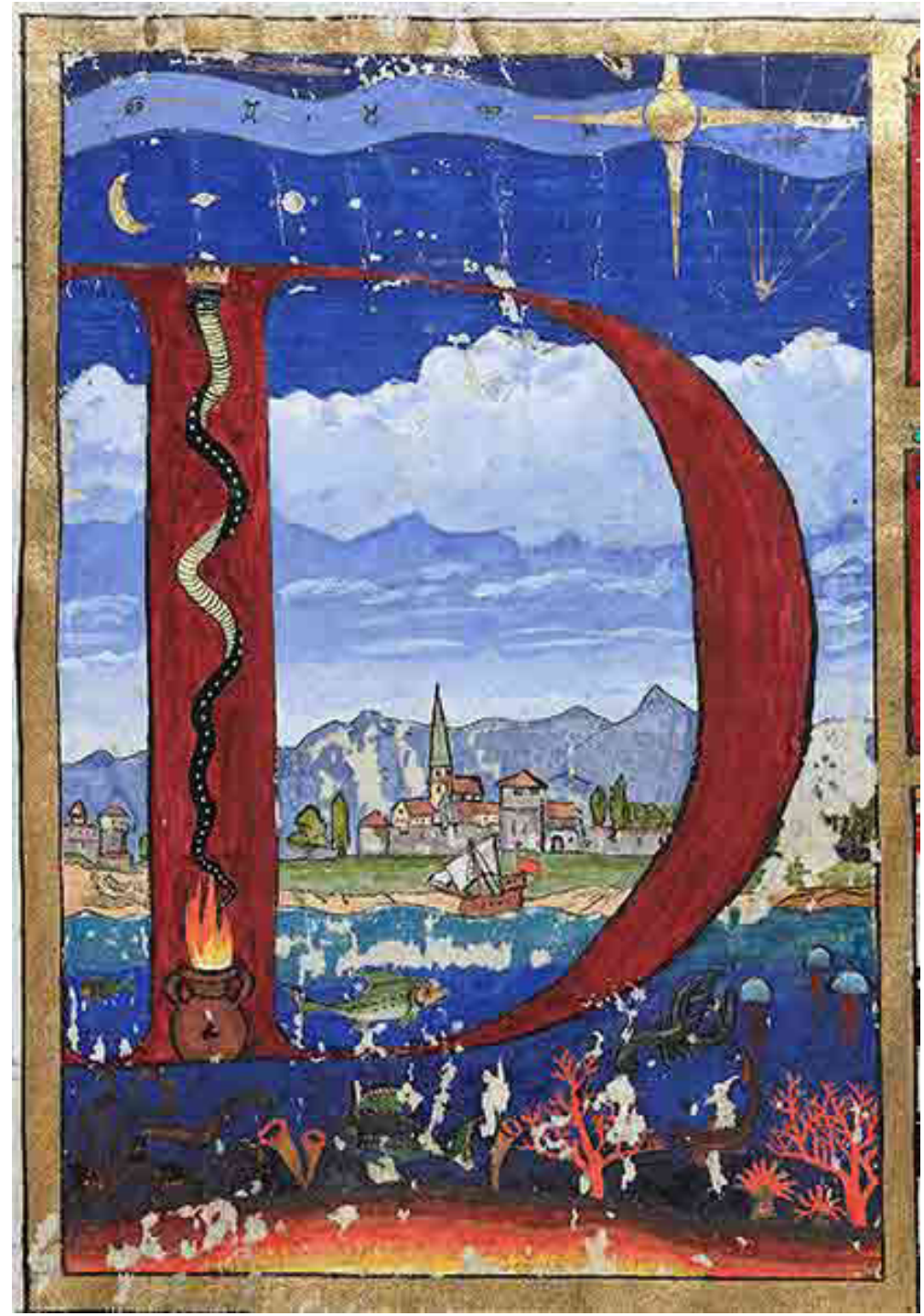

Fig. 1. Historiated Initial fol.1(r). (C) The Foundation of the Works of C.G. Jung, Zurich. Used with permission of the publisher, W.W. Norton \& Company, Inc. All rights reserved.

\footnotetext{
${ }^{10}$ By contrast, in Layer 2 of 'Remains of Earlier Temples', Jung likens self-conscious cycles of 'multiple rebirths' throughout life to the chameleon (XAMAI $\Lambda \mathrm{E} \Omega \mathrm{N}$ ): 'prone to changing colours, a crawling shimmering lizard' which protects itself and hides', as opposed to the lion, which gives life, and exists from its own force (RB RE:275-276 and n.94).
} 


\section{The Red Book, 1915-1929}

A systematic study of the calligraphic script in The Red Book confirms that Jung used colour experimentally and symbolically to emphasise certain aspects of the visual narrative. On the first parchment page, 'The Way of What is to Come', he painted the historiated initial 'D' an earthy dark red (Fig. 1: RB:fol.i(r); also reproduced in Art:Fig.29 and 244-245). The remaining letters of the title are blue, set against a red background. These contrasting primary colours of red and blue are the first visual clues to one of the important themes in Liber Novus and The Red Book: the appearance of opposites to be united by a reconciling symbol.

As in medieval manuscripts, Jung used red letters to highlight certain words in the Biblical texts that prophesy the new god in the opening paragraphs of fol.i(r), such as 'Isaias' (Isaiah), 'et' (for), 'despectum' (despised), and for the entire verse of Isaiah 35: 8, which succinctly prophesies Jung's 'Way':

And an highway shalt be there, and a way, and it shall be called the way of holiness: the unclean shalt not pass over it but it shall be for those[:] the wayfaring men, though fools, shalt not err therein. (RB RE:118-119).

Next to this red verse, he identifies himself and dates the foliocommon practice for medieval artists - choosing blue for the first letter of 'manu propria scriptum a C.G. Jung' ('written by C.G. Jung with his own hand') . Thus Jung designated his own 'hand' as 'blue', in contrast to the 'red' words of divine prophecies. On folio i(v) (reproduced in Art:Fig. 30 and 248), Jung employed red letters to indicate the beginnings of paragraphs, and larger red-and-blue letters to denote new sections. He thereby created a red-blue pattern that was further elaborated, or intentionally reversed, in successive chapters of Liber Primus and Liber Secundus.

\section{COLOUR IN THE CHAPTER TITLES OF THE RED BOOK}

\section{Liber Primus}

Having presented the opposing values of 'deep-red' and 'blue' in the letters of 'The Way That is To Come', Jung depicted the next seven chapter numbers in blue (cap. + roman numeral), and chapter titles in red, with a 
contrasting colour for the initial (historiated) letters (Appendix, 2). He used blue for those in 'Refinding the Soul' (cap.i), and the second of 'Experiences in the Desert'(cap.iv); in situations that surprised and challenged Jung's ego.

Gold is employed in a 'conventional' way, to denote the highest value, for the historiated initial of 'Soul' (cap. ii), where Jung's 'I' asks his Soul: 'are you God', and again: 'Who are you, child?' [...] are you God? Is God a child, a maiden?'." However, in keeping with the theme of transvaluation of earlier values, Jung also chose gold for the initial letters of 'Descent' (cap. v) and 'Splitting' (cap. vi), chapters describing his first active imagination, with its highly disturbing images, and his 'I's shocking realisation that his world differs from the Soul's and God's, thereby inverting gold's symbolic connotation. ${ }^{12}$

The historiated initial for 'On the Service of the Soul' (cap. iii) is painted in earthy red, an appropriate colour to represent Jung's doubting and fearful 'I', ego states that threatened to kill the 'holy trust' with his Soul. Jung used it again for the historiated initial of 'The Murder of the Hero' (cap. vii), here linking it back to the earthy-red historiated initial on folio i(r) that displays the triumphantly ascending serpent - the new god.

The grouping of these episodes into seven chapters suggests the seven days of creation, but in Liber Primus they culminate in a necessary destruction. Within them, red signifies the values of human instinct, emotion and suffering, as Jung's 'I' is made painfully aware of aspects of the Spirit of the Depths, himself and his Soul that he had previously ignored or undervalued whilst living in the Spirit of these Times.

The blue lettering of 'The Conception of the God' (cap. viii) proclaims a different presiding value. The Spirit of the Depths announces that it has received the 'sprout', the new god conceived in Jung's soul, and prophesises the nature and conditions of its impending birth, referring back to Isaiah's verses in the Prologue, as does the title's colour.

The final three chapters of Liber Primus form part of 'The Mysterium', Jung's mystery play, evoking the medieval Mystery Plays of Christ's passion and death. 'Mysterium' is lettered in gold, highlighting its supreme importance in this stage of Jung's initiatory journey. The subtitles of the three chapters are blue, relating them back

\footnotetext{
11 'Who' is written in blue, 'are you, child?' in red, and 'God' in blue. Jung is here forced to understand that his God (blue) is a child and a maiden (red) highlighting the incredulity that these images of God, child, and soul are the opposite of his previous convictions, as emphasised in Black Book 2: 'Should the daughter of man be God's name?' (RB RE:131).

12 Transvaluation is an important theme throughout Liber Novus, especially in 'The Remains of Earlier Temples' (RB RE:275).
} 
to the 'Way of What is to Come', and to 'The Conception of the God'.

Thus, already in Liber Primus, Jung has differentiated the various episodes by the four colour-values used in their titles: earthy red for the new god, bright red for the emotional rediscovery of his soul and for the suffering of his 'I' during subsequent trials and tasks, blue for the prophetic and spiritual aspects of Jung's initiatory journey, and for 'God', and gold to signal the highest value, even where unexpected.

\section{Liber Secundus}

Despite the fact that Jung transcribed parts of Liber Secundus over a longer period of time, his choice of colours for its titles follows a similar pattern. For the majority of the first sixteen chapters, finished by midSeptember 1922 (RB RE:360 n.212) he tended to use one colour for the initial letter or historiated initial, followed by a contrasting shade for the remaining letters, as in Liber Primus (Appendix, 2). The eleven chapters that narrate the emotional encounters of his 'I' with various personified characters have titles lettered in red, in contrast to the five chapters with blue lettering that recount significant spiritual encounters or challenges: 'Dies II', 'Death', 'First Day', 'Hell', and 'The Sacrificial Murder' (caps. $\mathrm{v}$, vi, viii, xii, xiii). Jung introduced turquoise, a colour formed by mixing green and blue, into the mosaic historiated initial of 'Death' ${ }^{13}$ From late September 1922, however, he chose black for the main lettering of the five chapter titles of the final section of Liber Secundus chronicling his encounters with black magic, red for the initial letters of caps. xviixix and xxi, but green for cap. $\mathrm{xx}$, 'The Way of the Cross', where the word becomes the saving symbol of new life (RB RE:391-392). ${ }^{14}$

Jung bestowed the same attention to the choice of colours he used for the initials of the interlocutors in the dialogue sections of The Red Book (Appendix, 2). Whereas the title colours serve to highlight the general narrative developments and symbolism within each chapter, those for the dialogue initials seem to indicate the differing attitudes of Jung's ' $I$ ' and the 'other' as he first narrates, then encounters and progressively

\footnotetext{
${ }^{13}$ In the revised version of A Study in the Process of Individuation, Jung noted that for Jakob Böhme "[...] "high deep blue" mixed with green, signifies "Liberty", that is, the inner "Kingdom of Glory" of the reborn soul' (1934:\$555).

${ }^{14}$ Green first appeared as a personification of Jung's 'I', whose 'garment bursts into leaf', in the text of 'The Red One' (LN RE:212-216). It becomes a symbol for natural man in 'Dies II' (ibid:262) and daimonic nature in 'The Remains of Earlier Temples' (ibid:269, 272-275).
} 
engages with the personifications of his active imaginations (Appendix, 2).

\section{COLOUR IN THE IMAGES IN THE RED BOOK}

Having examined the patterns in the coloured words, titles and interlocutor initials in The Red Book, there is clear evidence of Jung's symbolic intent. Turning now to the images, we will explore how Jung experimented with colour in a more sophisticated way, as he moved between simple forms and multifaceted visual works. ${ }^{15}$ Although colour symbolism is encoded in each Red Book image, I will only focus on some of those related to the themes of instinct and the cosmos, which Jung came to associate with feeling and spirit, expressed archetypically in the values of the colour spectrum.

\section{Liber Primus, 1915}

Behind the historiated ' $\mathrm{D}$ ' in 'The Way of What is To Come' on fol.i(r), Jung created a scene of the cosmos at the time of the birth of his new god, with its elements, painted according to Goethean colour principles (Fig. 1). At the bottom, the earth's fiery core radiates heat upwards in darkening layers of yellow, orange, and red (the element of fire; colours of dark over light). Above, the marine-blue sea, with its underwater creatures, gradually lightens in tone, becoming the blue and shallower blue-green waters of a lake. A red-flagged boat sails on its surface, and on the land above Jung painted two walled villages in a valley ringed by pale blue mountains (water and earth; colours of light over dark). Overhead, clouds lighten the blue sky, which darkens into upper space (air; light over dark).

The starry region above includes an astrological vision of the coming Aquarian age (Owens 2011:256, 267-75; Greene 2018b:156-68). At its summit, a light blue zodiacal belt snakes above the darkening sky. Glyphs

${ }^{15}$ See Éveno (2015), 'Jung's "Multicolored Arabesques": Their Renderings and Intentions in the Pictorial Vocabulary of The Red Book', which focuses on the different graphic vocabularies employed by Jung in The Red Book; first as related to drawings from natural sciences, pointillist mosaics, 'runes', and 'multicolored arabesques'; then by envisioning the arabesques as forms of 'dialectic between a fragmented chaos and a restabilizing or reordering, between an organizing factor and the insinuation of metamorphoses', linking them with psychical representations of physical makeup or 'skin-ness', shimmering waters, hidden images, powerful eruptions, and potential for transformation $(2015: 17,22)$. Many of his observations concur, while others differ, from those presented in this article, which-in contrast to Éveno's general psychological observations - aims to situate Jung's colour hermeneutics within the textual and historical context of The Red Book itself. 
for six of its twelve signs - Cancer to Aquarius - are displayed from left to right, in reverse of their natural order, thus representing the sun's precession through the vernal equinoxes, each change of sign indicating a new Platonic month or aeon. The golden sun, composed of a sphere and four cross-rays, gleams between the signs of Pisces and Aquarius, the current and future Platonic months. ${ }^{16}$ To the right below the sun, a gold comet - another celestial omen of impending birth — plunges towards the earth (Jung 1912:§499; 1952:§489).

Within the vertical stem of the ' $D$ ' superimposed on this scene, a serpent - the new god that was born at the end of Liber Secundusascends triumphantly from the flames of an earthenware pot decorated with a black phallus. ${ }^{17}$ Its crowned head is surrounded by three planets-a waning crescent moon on the left, Saturn, the planetary ruler of Aquarius, above, and Jupiter, ruler of Pisces, to the right - a conjunction prophesying chaos, the union of extreme opposites, and the birth of a new aeon. ${ }^{18}$

Most of the scenes and decoration of the historiated initials in the first five chapters of Liber Primus remain closely related to the unfolding narrative. In the following chapters, however, Jung began to create emblematic images in symbolic colours. Four in particular relate to his research on Gnosticism, Eastern cosmogony, astrology, and psychological types during the autumn of 1915.

Significantly, this series begins in cap. viii, 'The Conception of the God'. Its square historiated initial is a tiny flower mandala, (fol.iv(v) HI

\footnotetext{
${ }^{16}$ Jung first mentions the ancient astrological theory of the precessions and Platonic months in Psychology of the Unconscious (1912: $\S 186,308,683)$. He referred to it in a letter of September 1929 (1973,1:69), and treated it at length in the Dream Analysis seminars in 1929 (1984:421-31), and the Visions seminars in 1932: (1997,2:727ff).

${ }^{17}$ In Psychology of the Unconscious, Jung had cited the ancient metaphor of the sun's course through the zodiac as a snake carrying the zodiacal signs on its back, which he compared to the Mithraic leontocephalic god, also noting the Manichaean's attribution of the snake to Christ (1912:185 n.60). He depicted this visually in HI i(r): the 'great' zodiacal snake above, and the ascending serpent god with stars over its head. The black and white patterning on its skin symbolises the reconciliation of the opposites of light/good/day/love and dark/evil/night/forethinking, as developed in his Layer 2 commentary on the fight between the white and black serpents in 'Mysterium. Resolution' (RB RE:194-195, 199).

${ }^{18}$ The waning moon as a symbol of fear, death and destruction is discussed by members of Jung's 1929 Dream Analysis seminars (1984:371, 381). In Aion, citing the astronomer Albumasar, Jung stressed that the conjunction of the moon and Saturn in medieval times was identified with the age of the Antichrist, and that the conjunction of Saturn and Jupiter always 'signifies the union of extreme opposites' (1951:§§130, 131). Owens notes the Saturn-Jupiter conjunction above the serpent in Red Book HI 1(r) (2011:282 n.82).
} 
2; Zervas 2019a:182). The ' $G$ ' (Gottes, God) is blue, on a red background. In the centre of the space between them, a golden ball with a black circumference emerges. It is enclosed in a larger circle, divided by its eight rays, from which four elongate to form the petal axes. The petals are composed of successive white, pink, rose, and viola segments, the latter three mixtures of white, red, and blue. ${ }^{19}$ This the first time these colours appear in The Red Book.

The historiated initial pictures the emergence of the new god after the death of the hero. Significantly, the god's conception in the space between spirit (blue) and man (red) blossoms with colours that Jung would later relate to 'symbolic' blood and the archetypal image, located at opposite poles of the colour spectrum, rose towards the red end of dynamic emotion and instinct, and viola towards the ultra-violet end of the 'mystical' instinctual image (1954: §§384, 414ff). We may thus trace back the 'germ' of this idea to Jung's own artistic choices for fol.iv(v).

Jung's ideas are further developed for the ornamental border that frames the prophetic verses spoken by the Spirit of the Depth on the right column of fol.iv(v). ${ }^{20}$ Whilst appearing deceptively simple, this is a cosmogonic image, depicting the creation of the cosmos and its elements in time, whose dynamism is emphasised by Jung's particular choice of colours (Fig. 2: RB:OB fol.iv(v)).

At the top, Jung portrayed the cosmic realm. A downward-oriented flow of energies is initiated by two tiny sets of Vs in the corners of the gold background. A white circle, outlined in black, floats in the middle of the space: light and dark. As in the historiated initial, a golden ball emerges from the eternal, invisible mid-point. Eight rays extend from its circumference, forming a new sun. Behind it, an eight-point star fills the white circle. Each arm is a different colour: the star is a refraction of the sun's light. The arms containing the three primary colours - red, blue and yellow - form an triangle whose yellow apex descends along the vertical axis. It 'generates' the triangle of secondary colours - purple, green, and orange - whose purple apex ascends. Because the star has eight rays, Jung added two tertiary colours on the horizontal axis: red-orange (earthy-red) on the left, and blue-green (turquoise), important colours, as we have seen.

Below Jung depicts the creation of the earthly realm. A golden

\footnotetext{
${ }^{19}$ Although Jung used ready-made ground pigments to produce each of these colours, as discovered by Mellick (2018:114-135, 175-213), he was aware of their compound composition and placement on the colour spectrum.

${ }^{20}$ This image is discussed briefly by Éveno, who also suggested that its colours echo Goethe's research (2015:14).
} 
chalice, symbol of the cosmic crater of rebirth, is set against the chthonic black background, waiting to receive four drops released by the gold star above. ${ }^{21}$

These solar energies fertilise the contents of the chalice. New 'sparks' of eternal fire generate four ribbons of colour-brown, green, blue and red-that emerge from the chalice. They double and divide, then twist together and spiral up on both sides to join the white circle. Their colours represent the four elements: brown signifies earth, green water, blue air, and red fire.

They are also related to the zodiac: brown symbolises the three earth signs, green the water signs, blue the air signs, and red the fire signs. ${ }^{22}$ Jung was familiar with this interrelated elemental and astrological colour system. In his garden house at Küsnacht, used as an artistic studio in the summers, and also to display mandalas in the 1920 s, he decorated the interior south-east cornice with the glyphs of the zodiac, including the ruling planets in red over Aries (Mars), Taurus (Venus), Gemini (Mercury), Aquarius (Saturn) and Pisces (Jupiter), and a yellow sun between Aquarius and Pisces to indicate the current Platonic age (Fig. 3). ${ }^{23}$ The earth, water, air and fire signs are painted in the same colours as the elemental ribbons in the ornamental border of fol.iv(v).

In a Children's Dreams seminar of 19391940, Jung noted that the four elements were related to the four astrological (Platonic) months: Taurus (matter, stone, earth $=$ brown), Aries (fire

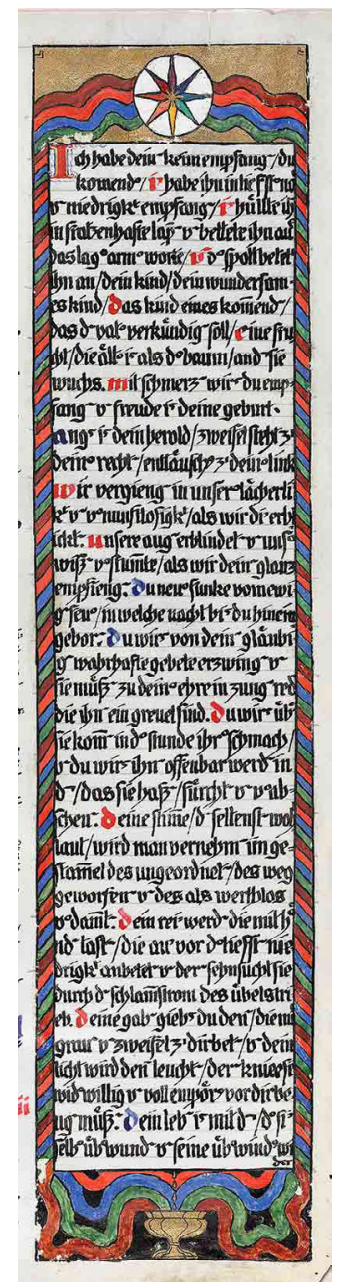

Fig. 2. Ornamental Border fol.iv(v). (c) The Foundation of the Works of C.G. Jung, Zurich. Used with permission of the publisher, W.W. Norton \& Company, Inc. All rights reserved.

\footnotetext{
${ }^{21}$ The crater as a symbol of rebirth appears in the three chapters of 'Mysterium' (RB RE:178-79, 184, 196; Jung 1989a:107); also see Kingsley (2018,1:197-198, 204-205). The chalice is a symbol of the Mater Coelestis in Jung's cosmological sketch and painting of the Systema Mundi Totius in 1916: discussed below. It is related to Gnostic vessel symbolism - the vase of sin and vas sapientiae of Sophia - and the medieval Grail, all symbols of the revaluation of the feminine and the soul (Jung 1923:288-290, 1921b:§396-398, 1989a:106-107; Kingsley [ibid]).

${ }^{22}$ Greene (2018b:23-24) discusses Jung's knowledge and use of the four elements.

${ }^{23}$ Diana Baynes recalled the garden house with its mandalas from a childhood visit in 1924 (Baynes Janson 2003:148-149).
} 
$=$ red), Pisces (water $=$ green), and the coming of the new age, Aquarius (air = blue) (Jung 2008:354-357). ${ }^{24}$ Therefore the union of the golden sun's drops and the primal chaos in the chalice in OB fol.iv(v) has produced the zodiac, which symbolises time. From the Pleroma, the opposites of light and dark have constellated, which then bring forth the coloured cosmos, with the sun, stars, elements, and time. ${ }^{25}$ It also reflects Jung's own transformation:

'Because I have fallen into the source of chaos, into the primordial beginning, I myself become smelted anew in connection with the primordial beginning, which at the same time is what has been and what is becoming'. (RB RE:179).

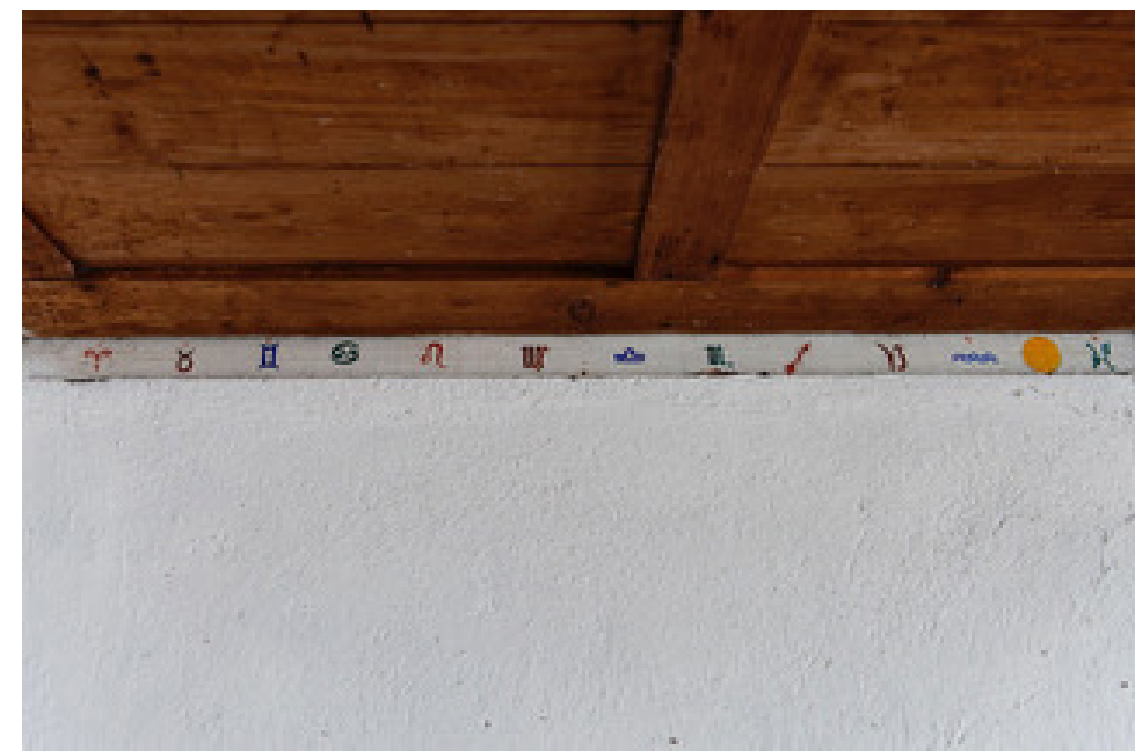

Fig. 3. Jung's Astrological Glyphs, The Garden House, Küsnacht. (C) The Foundation of the Works of C.G. Jung, Zurich.

Jung develops this cosmic dynamism further in the ornamental border on fol.v(r), which contains the 'Descendant' and 'Ascendant'

\footnotetext{
${ }^{24}$ Jung viewed this sequence of elemental/astrological stages as an image of a creative process, 'an emergence from the earth through water, through air, and through fire', noting that it existed in Pythagorean, Neo-Pythagorean, Neoplatonist and Gnostic philosophy, and that it corresponds to the four stages of individuation: ([winter term 1936/37], 2008:100-101).

${ }^{25}$ Themes taken up a few months later, in the initial sketch for Systema Mundi Totius: see below.
} 
houses in Jung's horoscope (Fig. 4). ${ }^{26}$ The two arched 'houses' flank the sixteen-rayed sun. On the left (west), a lion, symbol of the zodiacal sign of Leo - and Jung's natal sign — climbs down from the Descendant house ('D'). The red glyph of the sun, planetary ruler of fiery Leo-and also Jung's sun in Leo-is below the ' $\mathrm{D}$ '. To the right (east), the WaterBearer, symbol of airy blue Aquarius - and Jung's rising sign-has risen and come out of the Ascendant house ('O'). Above him is blue Saturn, his planetary ruler, with a waning crescent moon to its left (partly damaged). ${ }^{27}$ Saturn's glyph—also Jung's Saturn in Aquariusis beneath the ' $\mathrm{O}$ ', in harmony with the penultimate mantic verse in the text below: 'the constellation of your birth is an ill and changing star' (Saturn), which also relates to the gold-crowned serpent - the new godwith the crescent moon and the planet Saturn above it on fol.i(r) (Fig. 1).

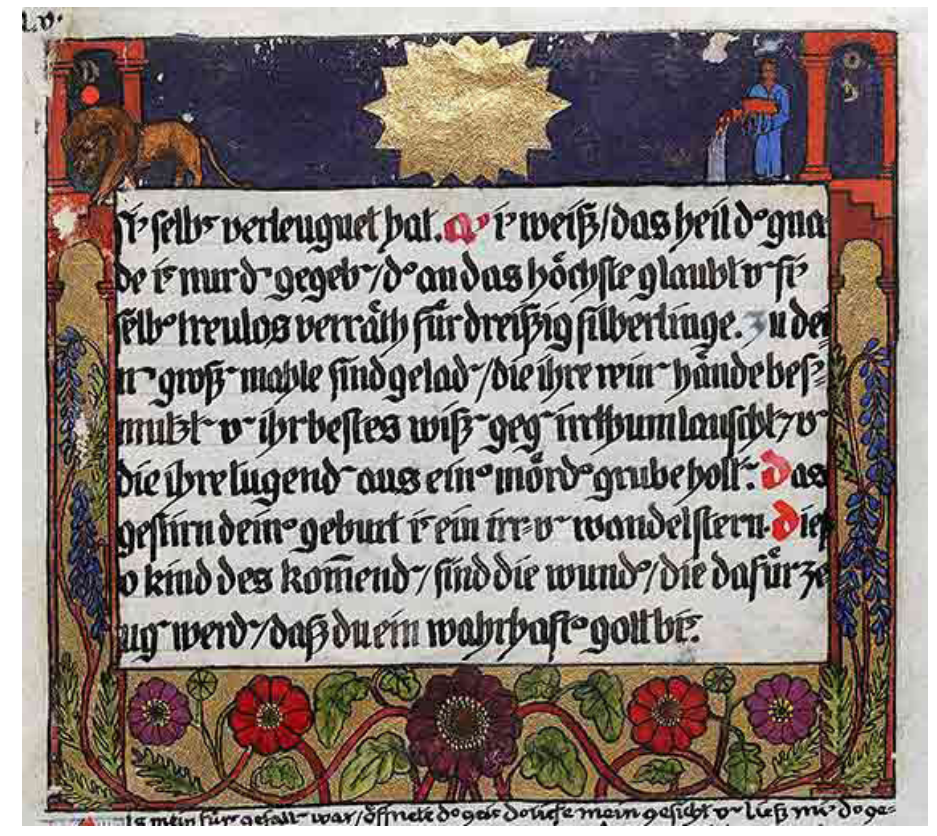

Fig. 4. Ornamental Border with Horoscope, fol. v(r) detail. (C) The Foundation of the Works of C.G. Jung, Zurich. Used with permission of the publisher, W.W. Norton \& Company, Inc. All rights reserved.

\footnotetext{
${ }^{26}$ Discussed extensively by Rossi (2015:38-42).

27 The colours of the planets ruling the zodiacal houses are identical with those of the houses' elemental signs, i.e. fire (red) and air (blue), as opposed the colours of the seven individual planets, which are related to their respective alchemical metals, such as: the sun gold and Saturn lead (black): Berthelot (1887,1:76-79), a source already known to Jung by 1911 (Jung 1912:137 n.36; see ibid. 1955:§390).
} 
Pictorially Jung has linked the colours of his birth with the conception of the new god in his soul and its birth in the coming Aquarian age. The theme continues in the gold-studded living waters that the WaterBearer pours from an earth-red jug, which change from red (Leo) to blue (Aquarius) as they flow. ${ }^{28}$ The lower frame of OB fol.v(r) is decorated with flowers and vines whose colours mirror those of the sun star in OB fol.iv(v) (Fig. 2), anticipating Jung's later remark that 'the sun descends into flowers, earth's answer to solar countenance' (1936:37, 1953:§99).

In the next chapter, 'Mysterium, Encounter', Jung expanded the range of symbolic colours he had used in 'Conception of the God'. The image next to the historiated initial on fol.v $(\mathrm{v})$ is divided into three parts: a central narrative scene, symbolic figures in the side and lower borders, and geometric imagery at the top (Fig. 5). In the narrative section, Elijah, the 'wise old man', is clad in blue; Salome, who desires Jung, wears a long red robe; and Jung's 'I' is dressed in an initiate's tunic of pure white. Jung placed a golden cross above Elijah's head, a golden circle above Salome's, and a red globe ringed with purple in the sky above his 'I'. ${ }^{29}$

In layer 2, Jung states that Elijah and Salome are images of forethinking and desire, his dominant and inferior functions (RB RE:179180). In the image, these qualities are portrayed symbolically in the side and lower borders of the picture. Jung represents forethinking by a blue diagonal square with Elijah's golden cross at its centre, from which ten sharp blue rays extend like multiple arms of a compass. Desire is fashioned as a red mollusc-like creature with a gold circle in its middle, whose five curling tentacles extend to entwine forethinking's rays. Each needs the other. ${ }^{30}$

\footnotetext{
${ }^{28}$ This theme is repeated in Image 123 (4 January 1920, RB:123), where the figure holding the holy caster of water is placed between a red sphere above him (Leo's red Sun), and a multi-toned blue one below (multi-ringed Saturn, ruler of Aquarius).

${ }^{29}$ The 'red moon' with its violet halo may be a symbol of the redeemed feminine, transformed from blind pleasure (Salome, Eve) to spiritual love (sighted Salome, Mary) in 'Mysterium. Encounter' and 'Instruction' ( RB RE:179-182; 189; 568-568; Jung 1989a:104-107). Astronomically, it is a lunar eclipse, caused when the earth moves between the sun and moon. Astrologically it has been associated with the time of Christ's birth, Crucifixion, and his second coming, as prophesied in the Book of Joel:2,31. This also would fit the narrative in the above two chapters, where Jung is first shown images of Eve, the tree of good and evil, and the serpent, symbolising the Fall of man; and then of Mary and the Christ Child, symbols of man's redemption through Christ. In the 'Mysterium', Jung will undergo Christification; man must become Christ, not imitate him.

${ }^{30}$ Salome's circle and Elijah's cross are later combined to form the 'quartered circle', an image of the reconciling symbol that appears frequently in The Red Book (see
} 
Their forms are closely related to Jung's ideas about psychological types as presented to the Psychoanalytical Congress in Munich two years earlier, in 1913. ${ }^{31}$ His remarks about Wilhelm Worringer's aesthetic theory are especially relevant. Worringer held that there are two forms of internal force (élan vital, libido) that inspire the artist, which he identified as abstraction and empathy: 'the urge to empathy finds its gratification in organic beauty'(Jung's symbol of desire); whereas 'the urge to abstraction discovers beauty in the inorganic, the negation of all life in crystalline forms' (Jung's symbol of forethinking) (1913:§871). ${ }^{32}$

Jung portrayed these concepts abstractly in the geometric top border, choosing different coloured diamonds to emphasise dynamic transformation. He placed red diamonds against a blue background on the left, and blue diamonds against a red background on the right. ${ }^{33}$ Moving inward from these two extremes, the diamonds change colours, moving through viola, light blue, and rose, to become white and gold in the centre: a Goethean progression from dark to light, from the instinctual to the mystical.

The examples discussed thus far demonstrate that Jung had developed a sophisticated colour hermeneutic by the time he finished executing Liber Primus in the autumn of 1915. This included his use of black, white, and gold; blue and red-spiritual and instinctual colours-but also related to his initial concepts of introverted thinking and extroverted feeling; the primary, secondary, and two tertiary colours symbolising the sun's energies; and the four elemental colours related to the creation of the earthly realm, the zodiac and time.

Zervas 2019b). In his writings, Jung associated it with the astrological sign for earth and the sun wheel, symbols of individuation, and the quaternity, which includes the feminine ([6 November 1929] 1984:341-342 [9 December 1931], 1997,1:500, 1938:88-89, 1958:§§125126). It is also related to the mandala (Zervas 2019a).

${ }^{31}$ See also Sherry (2010:18-19).

${ }^{32}$ At the Polzeath seminar, Jung explicitly identified blue with Logos and red with Eros, and man and woman, noting however, that ideally there should be a mixture of blue and red in the human. He added an explanation that is clearly based on the side and lower borders in Image fol.v(v): '(. . .) beyond the man is Logos, formal principle, crystallizing power; behind the woman, relations and relatedness-Eros. [ . . ]Logos is not just reaching out, it is the principle of crystallization, a giving form to, while Eros is creating in relation to, a dynamic reaching out [...] [Logos] is thought on the principle of crystallization. The crystal is growing, but from itself, rather than reaching out. Eros is like an animal that moves towards' (Jung/ Members 1923:63-65). Sonu Shamdasani alerted me to this unpublished typescript.

${ }^{33}$ See also Éveno (2015:18-19). 


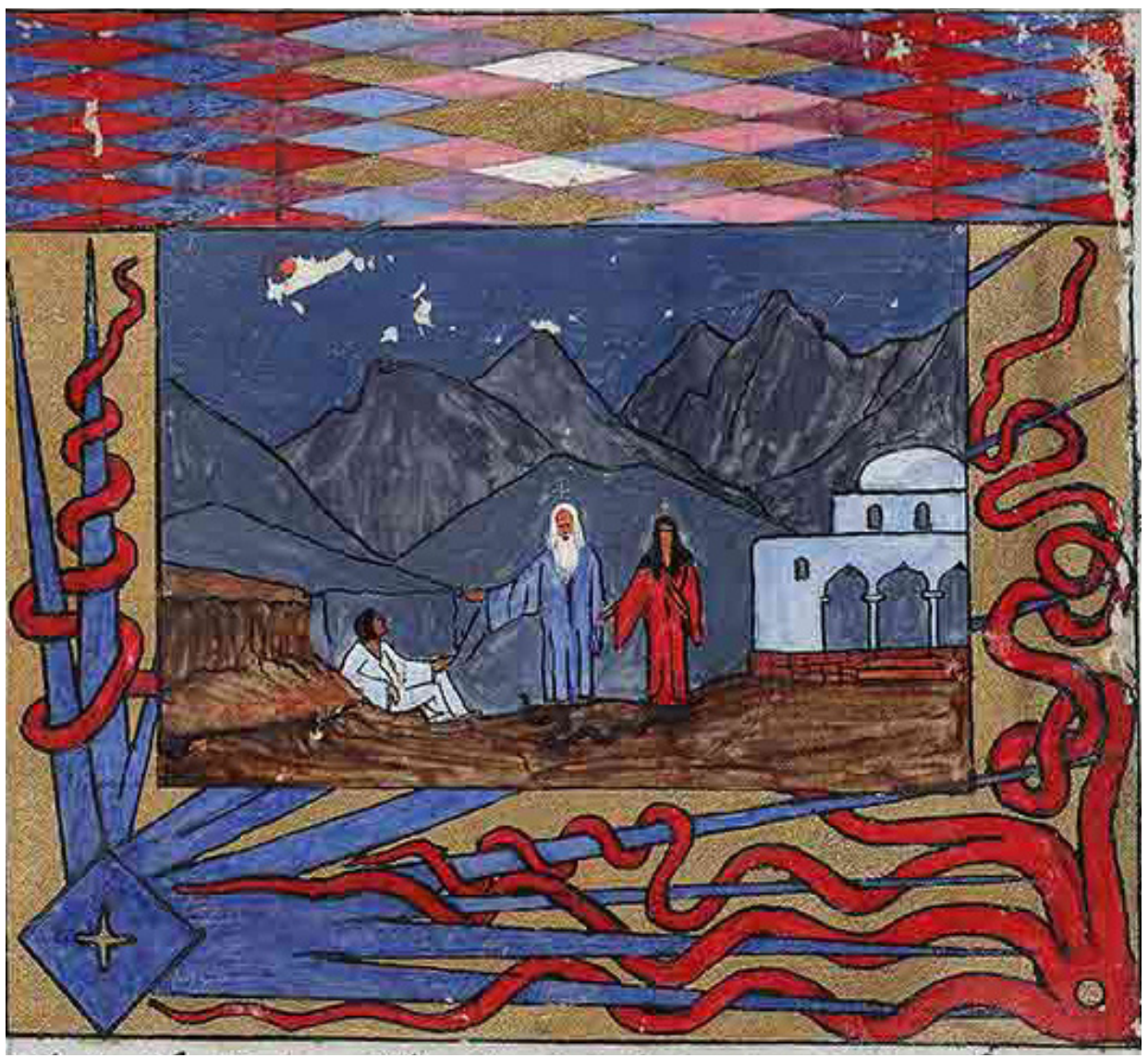

Fig. 5. Elijah, Salome, Serpent and Jung's 'I', Image, fol.v(v). (C) The Foundation of the Works of C.G. Jung, Zurich. Used with permission of the publisher, W.W. Norton \& Company, Inc. All rights reserved. 


\section{LIBER SECUNDUS, 1915-1929/59}

The visual images in Liber Secundus offer many avenues for exploring Jung's evolving colour hermeneutics over the next fourteen years. In this section, however, I will focus on three significant and interrelated themes: the disintegration and re-formation that accompany the birth of a new god; cosmic energies; and the ancestral souls. ${ }^{34}$

\section{Images of Disintegration and Re-formation, late autumn and winter 1915}

The historiated initial ' $\mathrm{D}$ ' for 'The Images of the Erring', which visually introduces Liber Secundus, is set in a square. The background depicts the four elements as embedded in the natural world (RB:1; reproduced in Art:251 and Fig. 73). Jung painted a light blue sky, and waves of blue water that sink into the multi-toned strata of earth. The upper layers around the ' $\mathrm{D}$ ' are static, but a tectonic force at the bottom has thrust four of them upwards, causing fragmentation. ${ }^{35}$

The cracking is most intense within the black ' $\mathrm{D}$ '. This area surrounds a heavily lined, hieroglyphic left eye with a gold cornea, red iris, and black pupil, whose midpoint is the centre of the square. A chthonic inner eye, it 'envisions' the seismic shift necessary for change: a mystical red sun that generates disintegration and the new world. ${ }^{36}$ The intitial's

\footnotetext{
34 The following colour analysis is deliberately detailed, in order to stress the dynamic emergence, rather than fixed nature, of Jung's colour hermeneutics during this period, and to honour his acute attention to the smallest coloured details, as confirmed by Mellick's studies of Jung's pictorial and chromatic techniques $(2018,2019)$.

35 See also Owens (2011:266); Éveno also discusses the theme of fragmentation (2015:8, 10-11).

${ }^{36}$ In a Dream Analysis seminar, Jung mentioned the myth of one-eyed Horus, who sacrificed his left eye to his father Osiris [Ra], whose left eye had been blinded by seeing evil; Jung therefore associated Horus with 'vision, view and healing' ([26 June 1929] 1984:285, 684). In the Visions seminars he stated that by Horus's sacrifice, the god received, like one-eyed Wotan, 'the wisdom of the earth'. Jung also described an Egyptian myth of the left eye of the goddess that is penetrated by the sun god in the autumn (the sun returning to the womb), the eye thus becoming an entrance to the dark underworld. From the Eastern point of view, however, Jung countered that the eye - an organ that symbolically creates light, rather than receiving it - is a creator, 'an expression that covers the creative fact within' ([18 March 1931] 1997,1:295-296, 304-305). I have been unable to trace Jung's source, which differs from the myth of the 'Eye of Horus' torn out by Set, restored by Hathor or Thoth, and offered by Horus to his dead father in an attempt to resurrect him, which symbolises protection and immortality, and is represented by the wadjet. Jung placed a golden 'left eye' of Horus on the solar
} 
stem contains a symbolic circulatory system with intertwining blue veins and red arteries. Its 'heart' lies in the same horizontal zone as the left eye, thus they are invisibly connected..$^{37}$ In the curved section of the ' $\mathrm{D}$ ', new life, a yellow-flowering vine, grows from a cracked layer below. ${ }^{38}$

As a totality, this historiated initial complements Jung's paradoxical use of Jeremiah's accompanying verses, which warn the faithful against false prophets, who 'speak a vision of their own heart', saying 'I have dreamed, I have dreamed. How long shall this be in the heart of the prophets that prophesy lies?' (RB RE:211). In Psychological Types, they comprised part of Jung's critique of Christianity, which had rejected as 'otiose and worthless' all individual fantasies after Christ's era (1921b:§81). In 'The Images of the Erring' that comprise Liber Secundus, Jung reclaimed them. He speaks the prophetic visions experienced by his own heart, destructive of older ones but necessary for the creation of a new god, leaving the post-Christian reader to sort the chaff from the wheat. ${ }^{39}$

The fragments from the striated layers of HI 1 are 'recycled' for the historiated 'E' of cap. iii, 'One of the Lowly'(RB:HI 11; reproduced in Art:252). Jung reshaped them into asymmetrical polygons that point toward the ' $E$ '. Moving inward, the shards diminish in size, then coalesce into minute tesserae in the four elementary colours, packed into tightening spiral curves. Whereas HI 1 represents a destructive process - from petrified order to chaotic fragmentationthis image presents a counter movement-from fragmented chaos towards elementary order-governed by an invisible centripetal force. In the historiated initial and image that Jung created for cap. vi, 'Death', the re-ordering process continues (RB:HI 29;

barque in two of the 'Incantation' series (RB:55, 64), and on two boats in a painting he made in 1919 (Art: Cat. 59 'Spheric Vision IV').

${ }^{37}$ Jung depicted the heart as a mirror image, with its right (blue) and left (red) sides reversed, still typical in medical illustrations. As part of the sympathetic nervous system, Jung's systolic/diastolic image, together with the 'left' eye, are the visual antecedents (and reminders) of his later comment that the sympathetic nervous system is connected with something psychic; as in HI 1, it sees 'with the eye of the depth' ([29 May 1929] 1984:236 and n.5).

${ }^{38}$ In Jung's initial sketch for this page (RB:363), the water flows down through the initial's stem to irrigate the tree that grows above the 'left' eye, clearly identified as such by the tear duct in its right corner (left in the drawing).

${ }^{39}$ In Baynes's translation of Psychological Types, the following phrases in Jeremiah's verses are italicised: 'vision of their own heart', and 'I have dreamed', emphasising the images of vision (the hieroglyphic 'left eye') and heart (the blue-red heart of the 'circulatory system') (Jung 1923:71). 
reproduced in Art:252). The lower part of the main scene illustrates the text's description of a new red sun forming in the dark sea:

Blood and fire mix themselves together in a ball—red light erupts from its smoky shroud - a new sun escapes from the bloody sea, and rolls gleamingly toward the uttermost depthsit disappears under my feet. (RB RE:264).

In the painting, the red sun is encircled by rings of orange and red, and then by the two 'noble' compound colours of rose and viola, surrounded by a purple sea. In the text, the sun had vanished beneath his suspended 'I', but Jung chose a new subject for the visual image. A black beetle, like the one in 'Descent into Hell of the Future' in Liber Primus (Image fol. iii(v) 1: reproduced in Shamdasani 2018:66), now emerges from the sun, its fearsome face painted in the 'old' alchemical colours of the redemptive opus: black, white, yellow and red. ${ }^{40}$ In the surrounding borders, the tesserae from HI 11 have become elementary geometric shapes used to construct the stick figures and other objects that represent incubation, rebirth and ascent. ${ }^{41} \mathrm{He}$ expanded the palette to include the colours of the multicoloured star in 'The Conception of the New God' in Liber Primus (Fig. 2).

Jung's extraordinary attention to symbolic detail and balanced opposites is evident in HI 32 (RB:32, also reproduced in Art:253), where blue, turquoise and gold tesserae make up the background of the circle that contains two egg-like forms, similar to those in HI 11. They are a contrasting pair: light and dark brothers. A mosaic Cabir, clad in red and white garments and a white pointed hat, nestles in the upper left 'egg', surrounded by earth-toned tesserae, encased in a double shell of pink, rose, and viola ones. Jung painstakingly reversed the colour sequence in the lower right 'egg', the Cabir is given blue clothing and a black hat; pink, rose, and viola tesserae surround it.

\footnotetext{
${ }^{40}$ Jung would have known about the ancient (synonymous with alchemical) colours from Berthelot, Collection des Anciens Alchemistes Grecs, which cited their origins (1887,1:144, 216); Herbert Silberer, Probleme der Mystik und ihre Symbolik (1914); and possibly from having attended Théodore Flournoy's 1912 lectures at the University of Geneva on a psychological interpretation of alchemy (RB RE:86). Black, red, and yellow are the predominant colours in Jung's vision in 'Descent into Hell of the Future' (RB: Image fol. iii(v) 2). He called them the four 'fundamental' colours when describing the 16 circles of 'rotating cosmic principles' in Red Book mandala 105, reproduced anonymously in The Secret Of The Golden Flower (1931b:138; changed to 'the four primary colours' in 1938:Plate A6).

${ }^{41}$ See Zervas (2019a:183-84).
} 
Interlude: The Cosmological Sketch and Systema Mundi Totius, 1916

\section{Sketch}

On 16 January 1916, Jung's soul instructed him about a new cosmology (Appendix C in RB RE:577-582). He elaborated it in the Seven Sermons to the Dead, written between 30 January and 8 February, and published privately later that year in a first attempt to communicate his ideas to a select group of colleagues. As in 1900, when Jung had made a diagram of concentric circles to illustrate the mystic cosmology of good and evil forces revealed to Helene Preiswerk (1902: $\S 65-69$ and text Fig. 2), so sixteen years later he did an annotated sketch of his new cosmology, with six concentric circles to delineate the different zones revealed by his soul. He used lapis and black ink, and highlighted some parts in red, blue, yellow and black crayon (Shamdasani 2012:122-123; Art: Cat. 42, 117; Zervas 2019a:183).

Jung divided the circumference of the innermost circle - that of the threefold soul (snake, man, bird) and Mankind (Anthropos) - vertically into two halves. In keeping with the colour symbolism already developed in The Red Book, he used red crayon to highlight the side containing the chthonic forces of snake/earth soul on the left, and blue for the spiritual forces of bird/heavenly soul on the right side. Ten blue rays form a star within the circle, the symbol of the individual and the one God, which is surrounded by yellow: the 'shining' clouds (RB RE:577-578, 580-581).

The $2^{\text {nd }}$ circle, labelled Man (Homo) is uncoloured. Jung continued the red/left-blue/right differentiation in the $3^{\text {rd }}$ circle of daimons (Daemons). Red highlights the left (sinister) energies-Phallus (the Devil), devils (the arrows), and the two flames of Eros on its vertical axis. The right (dexter) spiritual elements-the Mater Coelestis (Heavenly Mother), and the cup-like angels are reinforced in blue.

Within the $4^{\text {th }}$ circle of terrestrial heaven and earth, Jung used black ink for the astrological glyphs of Earth, mother of the Devil and the Heavenly World. He continued this for the $5^{\text {th }}$ circle of the gods (Dii), where only the glyph for the sun is coloured in red.

Jung divided the $6^{\text {th }}$ circle - the first distillation of opposites from the undifferentiated Pleroma - vertically into black (dark) and yellowgold (light) halves. The colours are repeated for the spheres on the horizontal axis: black emptiness (Spatium inane) on the left, deep yellow fullness (Vis Plenum) on the right, colours which repeat the upper and 
lower backgrounds of OB fol.iv(v); thus linking their cosmic meaning.

\section{The Systema Mundi Totius painting}

During September 1916, Jung had further discussions with his soul regarding his new cosmology. She explained the meaning of certain symbols that had appeared in the Seven Sermons to the Dead. Abraxas is 'the drive, who grows out of the Pleroma'. The individual is first a plant, without flowers and fruits, who grows from Abraxas's head. The individual is 'a passageway to the tree of seven lights; a 'precursor of the tree of light'. When the individual has been reunited with the world, with Abraxas, the tree of light appears, from which the light, Phanês, blossoms forth and flies ahead (RB RE:537 n.125). Jung then sketched her description on 15 October 1916, (reproduced in Art: Cat. 43; Zervas 2019a:183-184). ${ }^{42}$ Shortly thereafter, he decided to create a visual summa of his unfolding personal cosmology - the Systema Mundi Totius painting, incorporating elements from the Seven Sermons and the sketch (RB:364; reproduced in Shamdasani 2012:125; Art: Cat. 41, 116-118). After further reflections, in the autumn of 1917 he integrated the Seven Sermons to the Dead into Scrutinies, adding commentaries by Philemon and further editorial embellishments (Shamdasani 2012:121-123).

As Jung elucidated in 1955, the System Mundi Totius is a complex cosmological and psychological mandala (RB RE:561-562). In contrast to the six concentric circles of the cosmological sketch, Jung used three sets of seven concentric rings set around a centre circle in the Systema Mundi Totius ${ }^{43}$ Each seven-circle set represents a different macrocosm: repetitions that Jung described in 1955 as 'endless in number, growing even smaller until the innermost core, the actual microcosm, is reached' (ibid.). Significantly, the colour symbolism is also more elaborate. Jung added green, orange, two shades of blue, and gold to the original four alchemical colours used in the sketch, in order to depict the Systema's complex

\footnotetext{
${ }^{42}$ In the 'individuation' sequence Jung drew in his diary, he substituted the black beetle from the historiated initial in 'Death' in Liber Secundus (RB:29) for Abraxas, topped by the tree of life, the seven-branched tree of light, and the winged egg carrying Phanês, standing, with outstretched arms. He subsequently carved a variant in wood, and also had the motif engraved in agate and mounted on a broach for his wife (Art: Cats. 44, 47).

${ }^{43}$ See Jeromson (2005/6) for an introductory study of the relationship between the Seven Sermons to the Dead and the Systema Mundi Totius. Greene (2018a:142-176) attempts to interpret the Systema in terms of Jung's horoscope.
} 
energies, and differentiate chromatically its cosmic and human elements.

In analysing the Systema, we will follow the order of the Seven Sermons, which begin with the Pleroma and move inward to the Soul, Man, and the Self. The outermost, $7^{\text {th }}$ circle represents the first set of differentiation from the unbounded Pleroma. ${ }^{44}$ Jung divided it diagonally, into fourquarters, whereas in the sketch it had only been divided into halves. The left quarter and its sphere on the horizontal axis (labelled inane) are black. The right quarter is yellow, but its sphere (labelled plenam) is white. Thus, following his colour hermeneutic, Jung used black and white for the primary opposites of emptiness and fullness, and black and yellow to represent dark and light, as he had two years earlier, for OB fol.iiii(v) in Liber Primus (Fig. 2).

Jung then subdivided the top and bottom quarters of the $7^{\text {th }}$ circle into two halves, enabling him to create a 'diabolic' red segment on the left sides, and adding a reddish-orange segment - formed by mixing 'full' yellow + 'diabolic' red - on the right sides; labelling the latter 'the major external world' (mundus exterior maior). As we have seen, Jung had already used this compound colour for similar symbolic purposes in The Red Book, beginning with its first historiated initial in 1915 (Fig. 1).

The figure of Abraxas is also more fully detailed in the Systema painting. ${ }^{45}$ Indeed, this remains Jung's most complete rendering of the chthonic god, whom he here labelled 'ruler of the earthly world' (dominus mundi). Chthonic colours enhance Abraxas' image and symbolise his position within the cosmos. Described as the 'God above God', 'the effect of differentiation' (RB RE:517 ,522), Jung placed Abraxas at the lower end of the vertical axis, the only god in the $7^{\text {th }}$ circle. His black tail writhes between its diabolical and earthly segments, then his body, changing from blue to green, rises into the $6^{\text {th }}$ circle of the gods (dii), where his brownmaned lion-head is crowned by a huge 10-rayed gold star that extends through terrestrial and heavenly realms into the $4^{\text {th }}$ circle of the daimons.

Erikapaios Phanês (HPIKAПAIO $\Phi$ ANH $\Sigma$ ), Jung's new god and ruler of the spiritual world, occupies the opposite apex of the vertical axis, in the $6^{\text {th }}$ circle, a red figure with outspread arms, enclosed in a white egg with gold wings. ${ }^{46}$ Abraxas and Phanês are surrounded by

44 This circle is related to Sermons 1 and 2, which explain the Pleroma, creation, differentiation, God and devil: (RB RE:508-514).

${ }^{45}$ Abraxas is explained in Sermons 2 and 3 (RB RE:517-518; 520-522).

46 The figure of Phanês with outstretched arms is similar to one Jung made for the lower left border of the historiated initial Death in Liber Secundus (RB:HI 29), and to his diary sketch. Both fit the classical description of Phanês in The Psychology of the Unconscious (1912:§223). See Shamdasani (RB RE:358-359 n.211) for a discussion 
six golden stars, the gold Sun (deus sol) on the right, and the quartered black Satanic moon goddess (dea luna satanas) on the left. ${ }^{47}$ As in The Red Book, Jung uses gold to signify the highest value - here the gods. Jung's design for the $5^{\text {th }}$ circle, earth and heaven, is also more elaborate than the sketch. He divided it vertically: as in the relevant sections of The Red Book, using green for 'mother nature or earth' (mater natura s[ive] terra) and its sphere on the left side, and the light blue for 'heaven' (coelum) and its sphere on the right. ${ }^{48}$

Within the $4^{\text {th }}$ circle of the daimons (daemones), as in his sketch, Jung included the phallus (diabulus) on the left side, and the heavenly mother (mater coelestis) on the right. However, the images are more complex than those in the sketch: both are doubled. There are two phalli: a red one, whose shaft points inward, and a blue one, whose shaft points outward. Jung has painted them in the colours of devilishness and heavenliness. Similarly, there are now two chalices. In the sketch, the blue chalice faces upward, but here, a gold chalice faces inward, its base conjoined with a red chalice facing outward. Their designs illuminate the instruction on sexuality and spirituality in Sermon 5: "the sexuality of man is more earthly (the red phallus pointing inward), that of woman is more spiritual (the blue phallus pointing outward)... . The spirituality of man is more heavenly, it moves toward the greater (the red, outer chalice). The spirituality of woman is more earthly, it moves toward the smaller' (the inner gold chalice, relating back to the gold chalice in Fig. 2, OB vol.iv(v) (RB RE:528-29).

On the lower vertical axis of the $4^{\text {th }}$ circle of the daimons, above Abraxas, Jung added the tree of life (labelled vita), described as a devil-god in Sermon 4, and as a symbol of the individual-as-plant by Jung's soul in September 1916. It occupies the entire space of the $4^{\text {th }}$ circle; its roots rise from the $5^{\text {th }}$ circle of earth and heaven, and its crown abuts the perimeter of the $3^{\text {rd }}$ circle. To the left of the tree of life, Jung put a brown (earthly) beetle, similar to the two black ones in The Red Book (fol.iii(v) and Image 29), accompanied by a brown and white larva on the right. Above the larva Jung has written a description of this triad: 'human body and the one god and the interior, microcosmic world. death and future life' (corpus humanum et deus monos et mundi interiors minoresque. mors et vita futura).

On the upper axis of the $4^{\text {th }}$ circle of the daimons, Jung

of Phanês in the published excerpts of the Black Books, and Zervas (2019b:74-76) for Jung's later images of Phanês in The Red Book and other visual works.

${ }^{47}$ Explained in Sermon 4 (RB RE:523-526).

${ }^{48}$ Explained in Sermon 5, on the church and holy communion (RB RE:528-530). 
placed the tree of light, another devil-god. Its colour composition is a microcosmic recreation of the first differentiations of the Pleroma: the six black branches carry white flames (emptiness and fullness), whereas a yellow|red|orange|gold flame, labelled 'fire [of] Eros' (ignis eros) reaches upward from the central branch toward the spiritual world of Phanês (darkness and light). Facing the flame of Eros, still in the $4^{\text {th }}$ circle of the daimons, Jung added two composite creatures not previously included in the Systema sketch or the Seven Sermons. On the left (earthly) side is science, (scientia), imaged as a brown mouse with green dotted, blue butterfly wings. On the right, heavenly side, art (ars) is depicted as a gold-winged, green-and-blue segmented salamander, a motif Jung had earlier used to fill the background behind Izdubar (RB:36) ${ }^{49}$ Both unite the opposites of above (wings) and below (burrowing into the earth, the amphibious ability to bridge water and earth, and symbolic rebirth from fire). That Jung included science and art in the Systema indicates his relativization of them in the individuation process (i.e. nature and art, as opposed to his earlier assertion of nature over art) by late 1916, thus confirming, as he subsequently stated, that they are both 'servants of the creative spirit, which is what must be served' ${ }^{50}$

In his sketch, Jung had written АГАПН over the red flame in the lower part of the $3^{\text {rd }}$ circle of daimons, and solitudo over the flame in the upper part. For the Systema, however, he decided to dedicate an entire new circle to Love, based on the discussion of sexuality and spirituality, community (warmth) and singleness (light) in Sermon 5 (RB RE:528-530). Jung labelled the left, yellow half of this $3^{\text {rd }}$ circle 'heat, or natural (i.e. human/earthly) love' (calor s[ive] amor naturalis). The right half, 'cold, or the love of God' (frigus s[ive] amor dei), is coloured dark blue to differentiate it from the light blue used for the heavenly half of the $5^{\text {th }}$ circle. In Goethean terms, it would represent deep blue space. On the right horizontal axis, the white bird (labelled spiritus sanctus), flies towards the chalices of the heavenly mother.

Jung chose a flesh-toned pink for the $2^{\text {nd }}$ circle of Man. As he explained in 1955, this colour signifies 'the body or blood' (RB RE:561). A goldspotted, black serpent, whose colours unite light and dark, twists up on the left horizontal axis, circling behind the shaft of the red phallus. Thus the

${ }^{49}$ In 1955, Jung described it as a winged serpent, undoubtedly drawing on his alchemical knowledge, wherein winged salamanders, serpents, and dragons were often used interchangeably. See Greene for the astrological symbolism of the winged dragonsalamander in the Systema and Izdubar image (2018a:38-39).

${ }^{50}$ As said to Erika Schlegel in March 1921: see Shamdasani's discussion of Jung's attitude towards art during this period (RB RE:33-37). In 1955 Jung reiterated that 'art and science also belong to this spiritual realm' (RB RE:560). 
serpent/half-human soul/daimon of sexuality comes forth from the $2^{\text {nd }}$ circle of Man, whereas the dove/half-human soul/daimon of spirituality flies up from the dark blue half of the $3^{\text {rd }}$ circle, that of cold, spiritual love. ${ }^{51}$ The $1^{\text {st }}$ circle in the Systema is related to the innermost circle of the preliminary sketch. It encloses a 38-rayed blue star, superimposed over a 39-rayed gold one: the juxtaposition of Man's inner star and the distant star of the one God. ${ }^{52}$

Jung repeated this sequence of seven circles twice more, but reversed them vertically, first with the realm of Abraxas above and Phanês below, and then vice versa, before reaching the $8^{\text {th }}$ circle in the centre of Systema. It is divided into quarters and eighths, of the same six colours as the circumference of the outermost circle of the painting: black to the left (dark) quarter, yellow to the right (bright) one, and subdivided into red|orange eighths at the top and bottom segments. ${ }^{53}$ In 1955 Jung explained that this circle is 'the innermost core, the actual microcosm' (RB RE:561). It is surrounded by the 8-rayed blue star of the individual, and the 8-rayed gold star of the one God.

\section{The Cosmos and the Ancestral Souls, 1917-1929/59 Cosmic Elements, February-June 1917}

Following the Systema painting, Jung continued to experiment with cosmic themes during the first half of 1917, but in a more abstract way. Images 72 and 79, completed between February and early June

\footnotetext{
${ }^{51}$ The white bird and the serpent are discussed in Sermon 6 (RB RE:530-531).

${ }^{52}$ Explained in Sermon 7 (RB RE:534-535). The total of 77 rays may have had a symbolic significance for Jung. It is a repetition $(7,7)$ of the 7 cosmological circles of the Systema's macrocosm, which are repeated three times $(7,7,7)$. See also the soul's description of seven as 'the general and encompassing', and the seventh light as signifying the stars, on 25 September 1916 (RB RE:536 n.125). In Philemon's 'teaching' on Sermon 4 in Scrutinies $\{9\}$, he mentions the slaughter of the 7,777 cattle for which the dead have failed to atone (a fourfold repetition of 7: RB RE: 527). The symbolism of seven is extensively annotated Book II, Chapter X of Agrippa of Nettesheim's The Three Books of Occult Philosophy, which Jung owned. Its concluding quote by Livy seems especially relevant: 'The seventh light is come, and then all things/ To absolve the father of all light begins,/The seventh's of all things original,/The first seventh, seventh seven we call/Perfect, with wandering stars the heaven's [e]volved,/ And with as many circles is round rolled' (2017:273).

${ }^{53}$ Harms (2011:153 and n.23) proposed a different symbolic meaning for the colours in the Systema painting. Although he subsequently described the quarters of its innermost circle as green (left), orange (right) and red (above and below) (idem. 2016:130), digital enlargement confirms that they mirror precisely the colours and the order in which Jung divided the circumference of the outermost circle.
} 
1917, illustrate Jung's analogy between cosmic creation and the dynamic process in the psyche, by which irregular elements are formed in the deep unconscious, then assume rhythmic patterns, from which - through the four dimensions of space and time - the constituent shapes of the conscious individual arise. ${ }^{54}$ As before, his choice of colours heightens their symbolic meanings.

In Image 72 (Fig. 6), the cosmic matrix-undulating waves of square and trapezoidal elements in alternating shades of black and grey - is divided at regular intervals by six oscillating bands of smaller black and gold particles. Three pairs of vertical cones emerge from this medium. ${ }^{55}$ The two outer pairs are composed of an upper blue cone and a larger, lower green one. They expand away from each other, their apexes separated by a minute black dot. ${ }^{56}$ Conversely, the two centre cones expand inwards: the large upper yellow-orange cone faces the small lower red one. Thus, despite the vertical symmetry of their placement, the cones' dimensions and positioning energise the painting.

Jung's use of colour gradations reinforces this sense of dynamism and complexity. Like Goethean colours emerging from light and dark, the cones are lightest at their apexes. Their segments increase

\footnotetext{
${ }^{54}$ As such, they represent Jung's attempts to portray visually some of the themes in several seminal essays he wrote in late 1916 (Jung:1916a; 1916b; 1917).

${ }^{55}$ The cones are arranged on three vertical axes set approximately $5 \mathrm{~cm}$ apart. The upper blue cones and lower red cone are $11 \mathrm{~cm}$ long, but have different circle diameters $(5 \mathrm{~cm}$ and $4 \mathrm{~cm})$. The upper orange cone and lower green cones are different lengths $(15.5 \mathrm{~cm}$ and $14 \mathrm{~cm})$, but share the same circle diameter $(6 \mathrm{~cm})$. Cones form an important theme in The Black Books, Liber Novus, and some Red Book paintings. They make their first visual appearance in Image 72, form the black and white background of Image 75 (completed before June 1917), dominate the decoration of the back wall of Image 115 (1919), form the core of Image 121, and serve as the base of a wooden figure Jung sculpted ca. 1920 (Art: Cat. 46).

${ }^{56}$ Image 72 appears to be the pictorial antecedent to a discussion in Black Book 7 between Jung's 'I' and the black magician Ha about runes on 7 October 1917. Ha describes the upper and lower cones with their respective suns, explains that if their apexes meet they cannot be separated, and that he has therefore put a hard seed between them (RB 2012:325 n.155 referring to the runes in Image 89). On 3 June 1918, Jung's soul describes Philemon himself as 'the incorruptible seed of nothingness, which falls accidentally through space. The seed is the beginning, younger than all other beginnings, older than all endings' (ibid:372 n.230), strikingly similar to the cosmic dynamic of Image 72. Jung further amplified its meaning in the inscription to Image 121, the Lapis Philosophorum, dated November 1919 (where it refers to the tiny black diamond in the middle of that painting that separates four white, and black, diagonal cones): 'it is the incorruptible seed that lies between the father and the mother and prevents the heads of both cones from touching: it is the monad which countervails the Pleroma (ibid:372 n.229).
} 
in tonal density as they expand towards the viewer, before pooling into circular rims of green, blue, red and burnt orange, the elemental colours of water, air, fire and earth. ${ }^{57}$ The cones' terminating circles are cross-sections of their graduated colour tones, spiralling inwards from dark to light, thereby uniting their centres with their apexes.

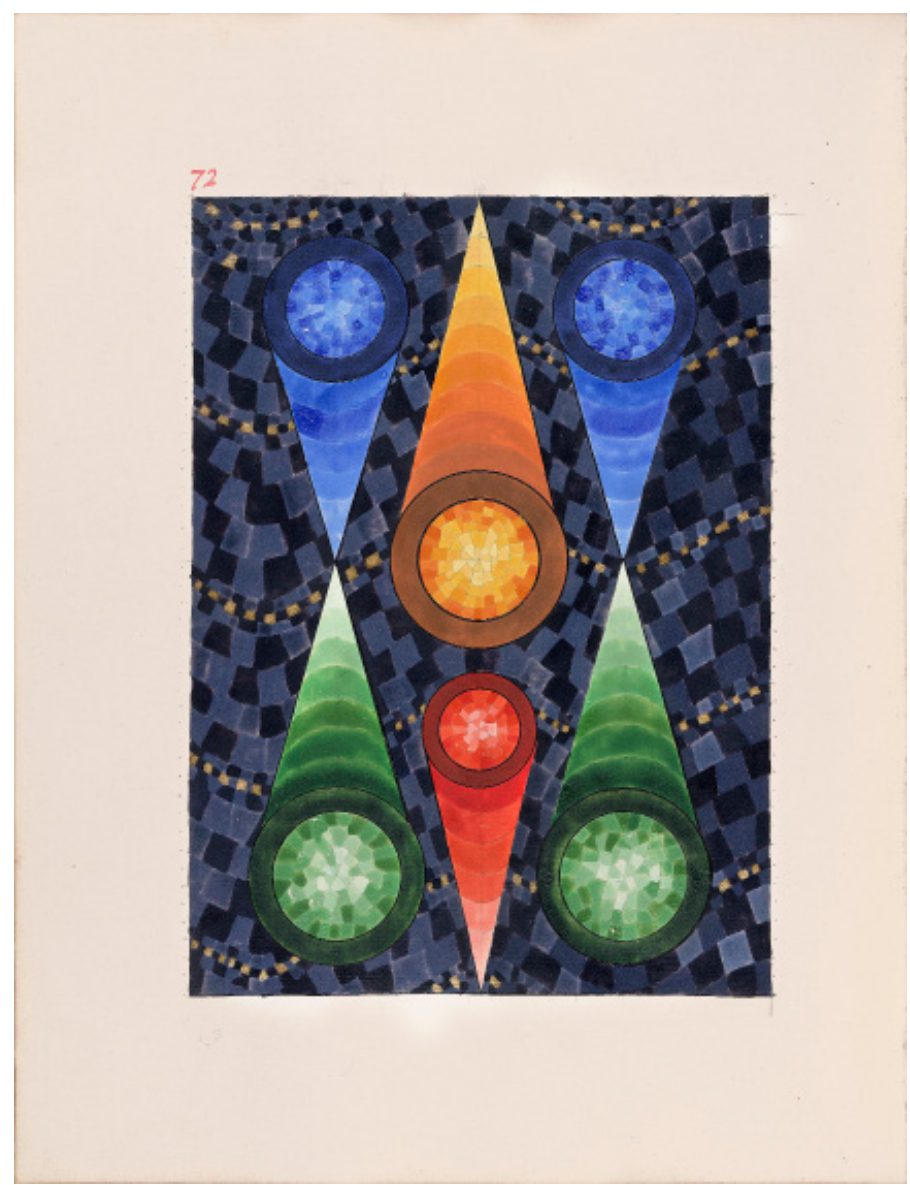

Fig. 6. Image 72. (C) The Foundation of the Works of C.G. Jung, Zurich. Used with permission of the publisher, W.W. Norton \& Company, Inc. All rights reserved.

Jung transformed this dynamic process into a symmetrical

\footnotetext{
${ }^{57}$ With their elemental colours, the cones seem symbolic of creation in time-space: the blue cones (air) ascend, the green ones (water) descend, their doubling suggestive of their elemental predominance, the gold-orange cone descends (earth) and the red one (fire) ascends.
} 
totality in Image 79 (Fig. 7). The cosmic matrix is formed of the same elements, but they now move towards the centre in centripetal patterns. The multiple gold and black bands in Image 72 have coalesced into a giant ring, too big to be fully contained on the page. Within its space, smaller elements in lighter tones form the circumference of a second circle, within which third one is formed from larger trapezoidal rectangles in the four elemental and astrological colours, reminiscent of Red Book HI 11. Four tangent circles emerge from its inner perimeter, outlined by tesserae alternating in the four colours. Moving from multiplicity to singleness, Jung then filled each inner circle with irregular polyhedrons in modulated tones of one elemental colour: orange, red, blue, green. Finally, he created a star-like cluster of irregular gold and black tesserae in the inner 'vessel' space between the four tangent circles. Image 79 is Jung's first full-page 'mandala' in The Red Book. It was completed months before the mandala sketches that he drew at Chateau d'Oex over the summer of 1917, and subsequently paintedreplete with black and golden seeds-in The Red Book during the following autumn and 1918. A cosmic mandala, it relates back to the earlier image of dynamic creation that Jung represented in the ornamental border for 'The Conception of the God' in the autumn of 1915 (Fig. 2 ). Whereas the latter provides a vertical viewpoint, in Image 79 Jung presents a cross-sectional view of the cosmic vessel, formed within the outer rings that have differentiated themselves from the Pleroma, whose black and gold seeds 'spark' the four elemental circles into life. 


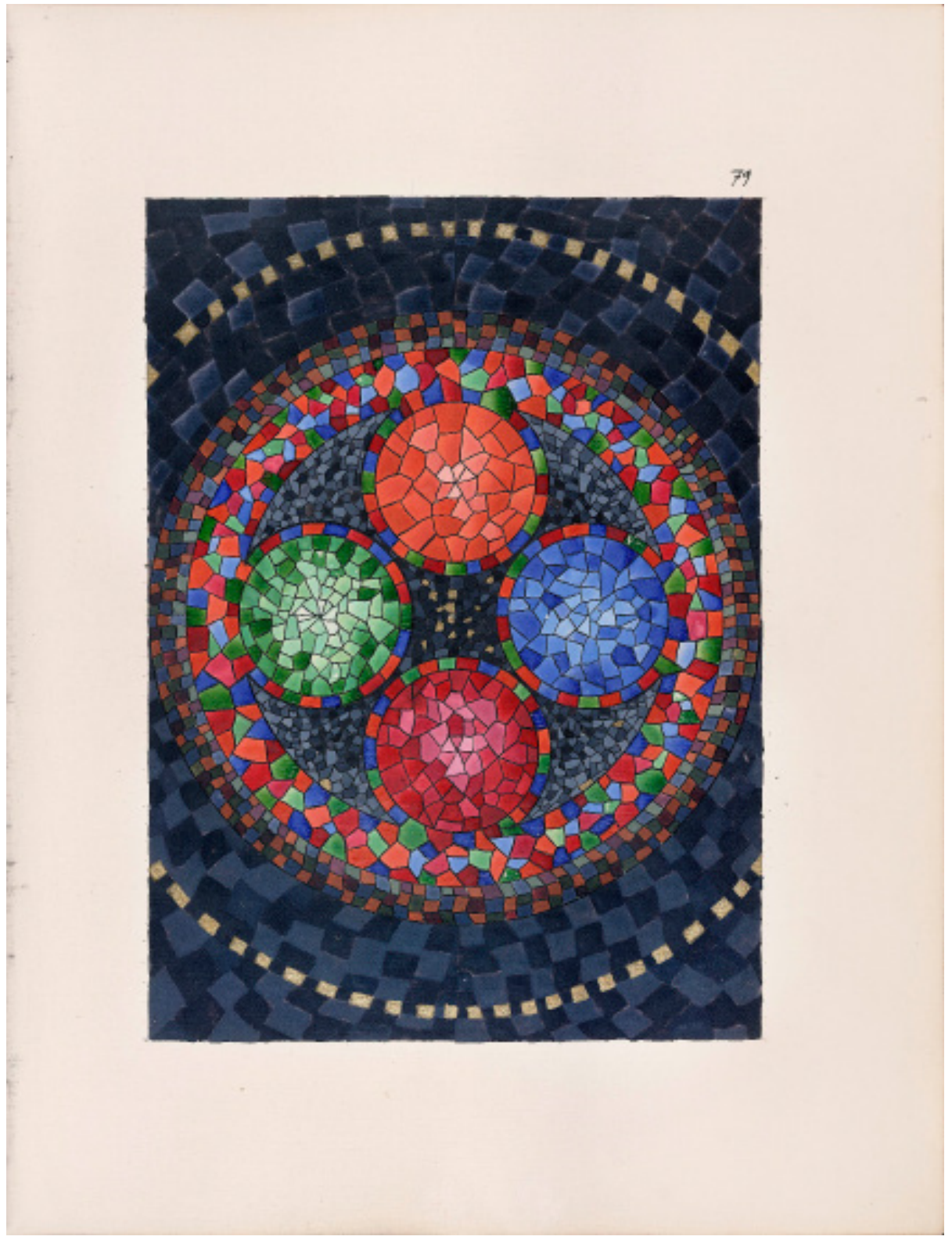

Fig. 7. Image 79. (C) The Foundation of the Works of C.G. Jung, Zurich. Used with permission of the publisher, W.W. Norton \& Company, Inc. All rights reserved.

This vision of cosmic energies and formation fits Jung's 
subsequent description of the mandala in a Dream Analysis seminar, as a ground plan of the structure of the psyche, whose psychological constituents he likened to the four elements, and the four gates of consciousness (29 January 1930, 1984:453). ${ }^{58} \mathrm{He}$ called these elements Mendelian units, the remnants of our ancestral souls (1984:453-454). ${ }^{59}$

Jung expanded this analogy in a 1938 Zarathustra seminar, abetted by his increased alchemical knowledge, in a way that perfectly describes Image 79 . He portrays the psyche as a disjointed puzzle, sometimes represented in dreams 'by the motif of a swarm of small particles', disparate elements that need to be reunited. This process 'begins with the idea of totality, which is depicted as a circle', which is called 'chaos' - the massa confusa - that consists of a chaotic collection of dissimilar elements:

The symbolic idea is to arrange the particles in a sort of crystal-like axis, which is called the quaternity [...], and to each point a particular quality is given. The four quarters of the circle indicate the fire, the air, the water, and the earth regions, and when they are arranged they will make in the center the quinta essentia, the fifth essence. [...] It is again

\footnotetext{
${ }^{58}$ This seminar appears to be the first time that Jung related the four colours of the Buddhist mandala (red, blue, yellow, and green) to the 'modern' colours preferred by his patients for active imagination, rather than the four 'fundamental' or 'ancient' colours of white, black, yellow and red, or the 'elemental' colours of green, orange, red, and blue. The 'modern 'or 'basic' colours, which Jung also called the four colours of the rainbow, represent the four typological functions (respectively feeling, thinking, intuition and sensation). When joined together they form a totality whose synthesis symbolises the integration of the personality (Jung 1934:§582; 1936:113 and 1953:§287; 1937:12, 19 and 1955:§390; 1939:164, 167, 185-186). Although citing his patients' material, Jung clearly had his Red Book images in mind (1931b:138 nos. 3, 6, 10 and Plates 3, 6, 10 and 1968:Plates A3, A6, A10).

59 Jung first mentioned Mendelian concepts in Psychology of the Unconscious (1912: §361 n.50). He referred to Mendelian units as constituent elements of the psyche numerous times between 1925-1938, particularly in his seminars ([20 April 1925] 1989a:39; [16 October 1929] 1984:311-312; [20 January 1930] 453-454; 1931a:§§140141; [31 January 1934] 1997,2:1266; [30 October 1935] 1989b,1:643; [10 June 1936], 1989b,2:986; [9 November 1938] 1399-1403; [1936/37 term] 2008:73-74. They are described as ancestral souls in the ETH seminars ([15 December 1933] 2019b:78), and as traits or elements of ancestral character requiring integration his 1936 Baily Island Seminar (2019a:173, 202-203). Jung continued to employ this analogy throughout his career, including Memories, Dreams, Reflections: 'Our souls as well as our bodies are composed of individual elements which were all already present in the ranks of our ancestors. The "newness" in the individual psyche is an endlessly varied recombination of age-old components. Body and soul therefore have an intensely historical character and find no proper place in what is new, in things that have only just come into being' (Jung/Jaffé 1963:223).
} 
that circle of the beginning but this circle has now the anima mundi, the soul of the world, which was hidden in chaos [...], and the self is the quinta essentia. (1989b,2:1400-1402).

The cosmic and psychological aspects of Image 79 are further amplified by Jung's comments during a Protocol interview in 1958 . He began by recounting a dream by a patient (then deceased) of a shawl edged with real gold, whose centre was decorated with gold discs or sparks, as if struck from an anvil, that scattered and then came together again, as if created anew. This dream reminded him of his early mandalas, 'where black magnetite (magneteisen) seeds and gold seeds were mixed, and must be brought together in the central vessel that is the self'. The black seeds, as magnetite, 'come from the sky'; they are 'meteorite iron', 'particles [that] attract'. The gold seeds between them are 'brilliant elements, luminous particles in the dark material'. Psychologically, Jung explained, 'the dark particles are without libido or consciousness, and the bright, golden [particles] are the original elements of consciousness', that can't be detected at first, but will become visible in the daylight. Their energies can suddenly generate an image, which then can be integrated, 'forming the foundation of the vessel [of the self]'. Jung also related them to the mosaics at the $5^{\text {th }}$ century tomb of Galla Placidia in Ravenna, 'a place where these gold clumps exploded and came together' (Protocols [20 March 1958]:333335). ${ }^{60} \mathrm{He}$ was undoubtedly referring to the mosaic in the central crossing of the Greek-cross building, which depicts a circular, inward and outward swirling pattern of eight-rayed, gold stars set against a deep blue background (almost black when viewed from below), with the Four Evangelists in the corners, and a gold Latin cross in the centre-a Christian mandala (Fig. 8).

\footnotetext{
${ }^{60}$ Jung visited the tomb of Galla Placidia in 1913, 1914, and 1923. Following Red Book Images 72 and 79, he continued to experiment with the motif of black and gold seeds in the series of mandala paintings based on his sketches, Images 79-96, completed between October 1917 and early 1918. In the section of Scrutinies $\{12\}$ that he added to the 7th Sermon to the Dead in the late autumn of 1917, Philemon explains to Jung's 'I' that he has saved life - as duration and eternal being, 'the black and golden seed and its blue starlight' - from time, 'the fire that flares up, consumes, and dies down (RB RE:536). Jung had already chosen black, gold and blue as colour signifiers of duration and eternal being for the abstract decoration within the historiated initial for 'Mysterium.Encounter' (RB:HI fol. v(v)) in Liber Primus, completed two years earlier, in 1915.
} 


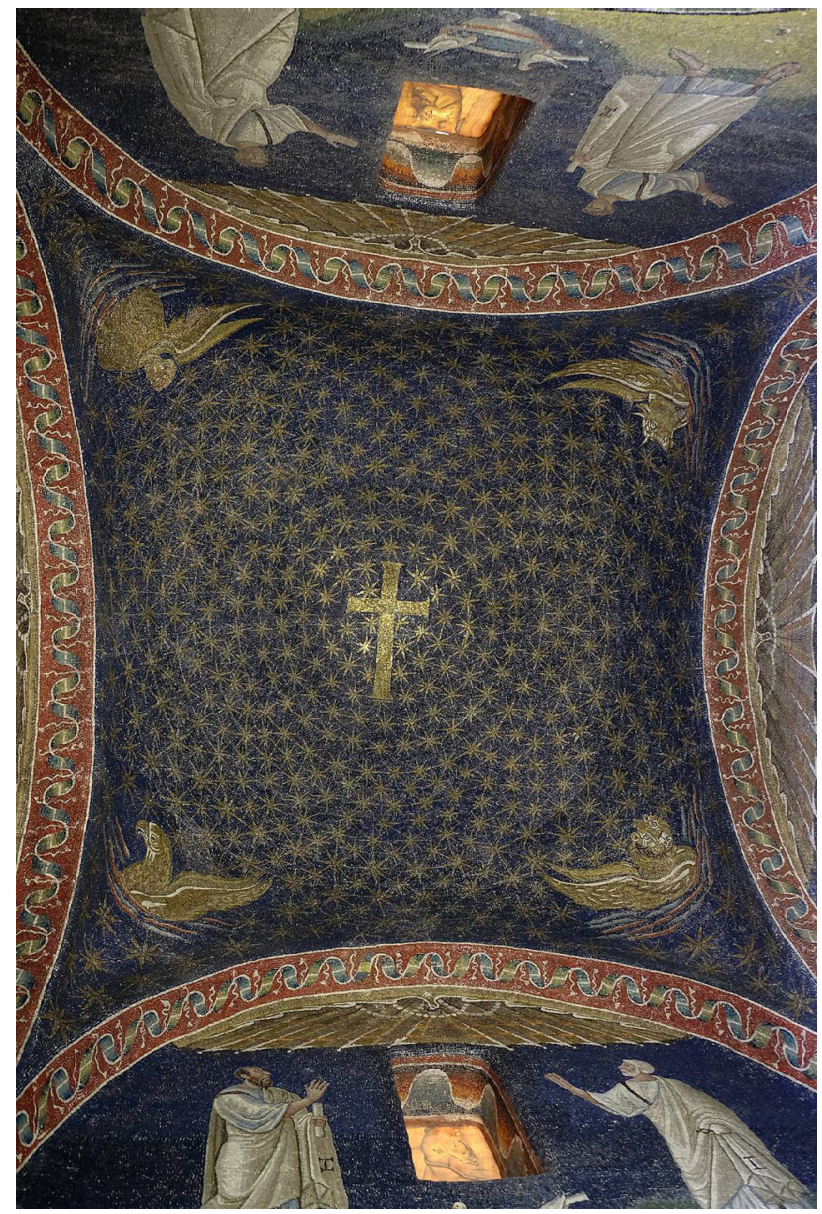

Fig 8. Central Crossing, Mausoleum Galla Placidia, Ravenna (Italy). Free download from: https://www.cepolina.com

The Self, Individuation and the Ancestors: Image 169 (unfinished), 1929/59

When Jung stopped work on The Red Book, he left Image 169 unfinished. Nor could he complete it in 1959 (Fig. 9). Whilst remaining open to many interpretations, ${ }^{61}$ and awaiting possible amplification in the forthcoming publication of the Black Books, Image 169 is nevertheless related to Jung's contemporary ideas about ancestral souls as constituents of the psyche that require integration for further analytical development. Following Jung's colour experiments between 1917-1927, the painting presents us with Jung's concluding - although not final-'coloured thoughts' in The Red Book.

At the lower left, Jung designed a mandala that transforms from a

${ }^{61}$ See Laughlin, Treasure Hunting (2016) for a summary. 
diamond-like 'philosopher's stone' to a circular 'flower' with 16 petallike lobes. In the middle, against an ice-blue background, a diagonally quartered, white square is set within a second one, which in turn is framed by an equal-armed white cross. Around this central structure, triangular and tetrahedron facets in white and deepening hues of blue multiply outward from 8 to 12 to 16 , the latter the traditional number of the sun's rays. ${ }^{62}$ The mandala is surrounded by 128 rays in alternating colours of red, yellow, green and blue (right to left). Jung noted their order in pencil at the lower left of the page: roth, gelb, grün, blau. They are the colours related to the four psychological functions of consciousness (feeling, intuition, sensation, thinking). Thus the mandala presents a symbol of individuation: the diamond/flower/self from which the rays of consciousness emanate.

Concentric rings of 127 faces (one less than the mandala's rays), some complete, others still unfinished, orbit around this new sun. They represent the living, the dead, and the ancestors-another major Red Book theme. Those closest to the mandala's rays are highlighted in white, whereas the unfinished faces in the outer rings vary from whitish green, turquoise, to blue-green at the edges - continuing the movement from light to dark. Several skulls leer out along the right edges of the painting, and in the upper right corner, a skeleton stares at us, its bony arm gesturing at the other faces. Lower down, a Neanderthal-like profile stares towards the mandala.

\footnotetext{
${ }^{62}$ Jung designed a simpler version of this type of mandala for his fireplace mantle, carved during the 1931 additions at Bollingen. He linked this configuration - the transition from a cross to a rose ('per crucem ad rosam') - to the Rosicrucian 'Rosie Crosse', and the movement from the Christian era to a new age (1936:37 and 1953:§99).
} 


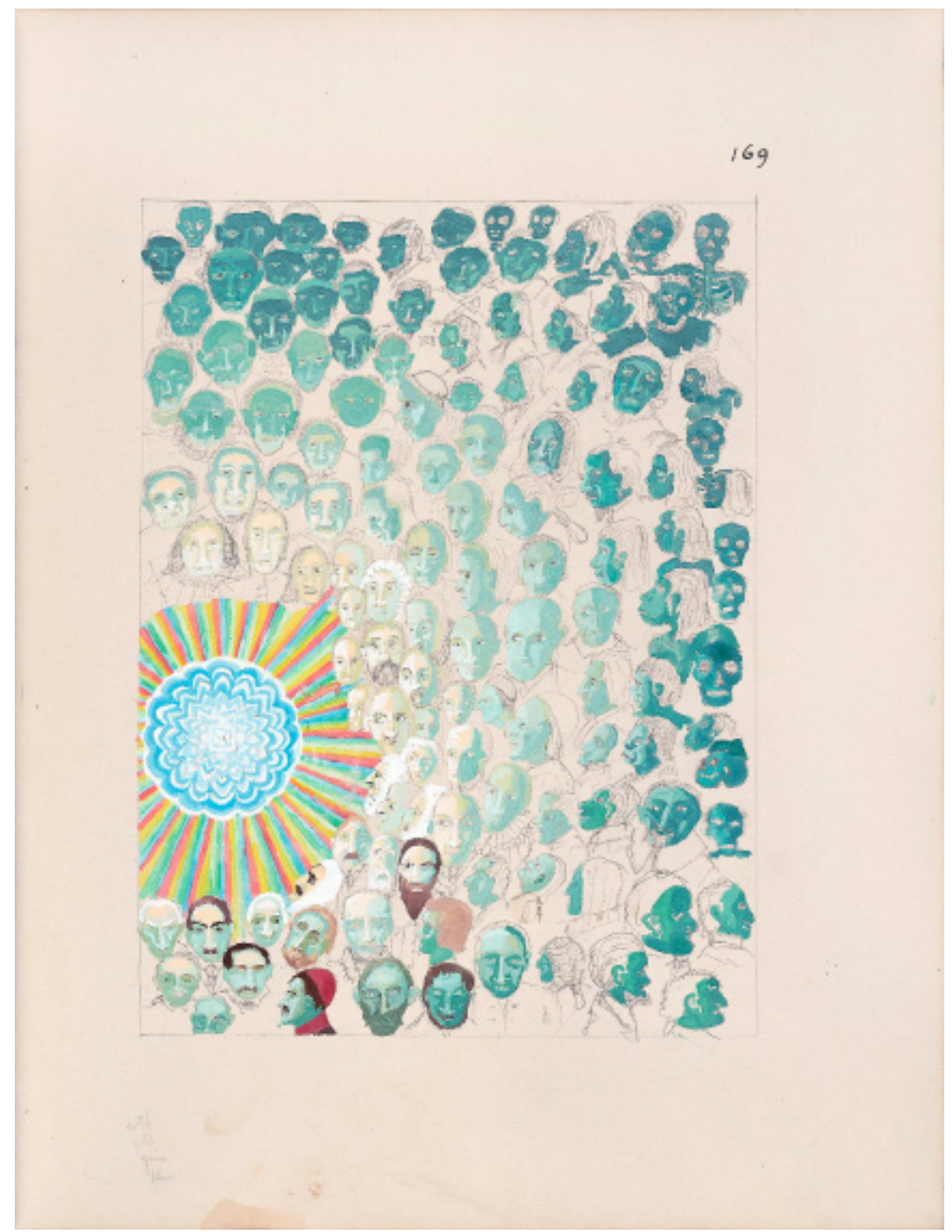

Fig. 9. Image 169. (C) The Foundation of the Works of C.G. Jung, Zurich. Used with permission of the publisher, W.W. Norton \& Company, Inc. All rights reserved.

On a collective level, they signify the progressive waves of emerging 
consciousness that have been completed - or remain incomplete-over the aeons of human history, moving inward from mankind's remotest beginnings on the right side, to the present, closest to the mandala on the left. On an individual level, they represent the ancestral souls, the Mendelian or psychic elements that require unification (drawn to the mandala). For Jung, they undoubtedly included his ancestral dead and the historical figures who were important for his own psychological make-up and individuation. ${ }^{63}$

\section{CONCLUSION: 'THE BEAUTY OF SUFFERING'}

At the end of Scrutinies, a blue shade, identified as Christ in Black Book 6, enters Jung's garden. Philemon welcomes him, observing that 'the sins of the world have conferred beauty upon your countenance', describing them as crimson (blood), ermine (snow from the poles), and crown (the sun) - the 'old' colours of red, white, and yellow/gold. Christ asks: '[...] are you in my garden or am I in yours?' Philemon answers that Christ is in Baucis and Philemon's garden. He is able to be there because the couple, hosts to the Gods, have already given hospitality to Christ's brother, Satan, the terrible worm. Within this new order, Christ brings a gift for the future generations of the approaching Aquarian age, where evil must be acknowledged and lived with—dark together with light—in each individual. Christ's gift is paradoxical: 'I bring you the beauty of suffering' (RB RE:551-553). He bestows his suffering, and its beautiful colours, to mankind.

Through Jung's acts of colour exploration, The Red Book presents its viewer with a striking visual journey, one depicting Jung's 'beauty of suffering', thus linking it with Goethe's assertion a century earlier: 'colours are the deeds and sufferings of the light'. The Red Book teaches that there is no individuation without suffering and

\footnotetext{
${ }^{63}$ As Laughlin has most recently noted (2016:314), Image 169 is related to a dream Jung had when working on The Psychology of the Unconscious in 1911, recounted in Memories, Dreams, Reflections. He met a group of 'distinguished spirits or earlier centuries', including a bewigged gentleman (of which there are several in Image 169): 'The bewigged gentleman was a kind of ancestral spirit, or spirit of the dead, who had addressed questions to me - in vain! It was still too soon, I had not yet come so far, but I had an obscure feeling that by working on my book I would be answering the question that had been asked. It had been asked by, as it were, my spiritual forefathers, in the hope and expectation that they would learn what they had not been able to find out during their time on earth, since the answer had first to be created in the centuries that followed' (Jung/Jaffé 1963:284-285). Laughlin attempts to identify these figures (ibid:374-386).
} 
sacrifice, and Jung employed colours to signify their type and intensity.

As I have demonstrated, by the time that Jung had finished the calligraphic version of Liber Primus on parchment, and the first 36 pages of Liber Secundus in The Red Book in late 1915, he had already developed his own colour hermeneutics, which he continued to expand and refine during the next fifteen years. On the simplest level, his choice of colours signified the feeling-toned aspects of his 'I', soul, other personages, and chapter titles in Liber Novus. With increasing sophistication - and recourse to historical precedents - he also selected colours to symbolise the instinctual aspects of the psyche, the cosmic elements that linked Man to the new God and the Pleroma, and his developing ideas about typology. By 1921 Jung could state with personal conviction: 'Everything that is alive in the psyche shimmers in multiple colours' ('Etwas in der Seele schillert in mehren Farben'). ${ }^{64}$

We have had to wait nearly a century, until the publication of The Red Book, to appreciate more fully the meaning of Jung's declaration. It provides us with a key to comprehend his colours of dread ('Descent into the Hell of the Future') and love (images of cosmic creation and hierosgamos that could easily have illustrated Mysterium Coniunctionis over three decades later); in short, to respect their effectiveness and numinosity, from the tiny coloured hieroglyphics on Red Book 42 to the monumental mandala at Bollingen. For just as Liber Novus reverberates silently throughout Jung's subsequent corpus of writings, so his Red Book colour hermeneutics shimmer in the background of his subsequent discourses on colour symbolism.

dianezervashirst1@me.com

${ }^{64}$ Jung (1921a:701; differently translated in 1921b:\$854). 


\begin{abstract}
ABBREVIATIONS
Art $=$ The Art of C.G. Jung. 2019.

RB = Jung, Carl Gustav. 2009a. The Red Book.

RB RE = Jung, Carl Gustav. 2009b. The Red Book, Reader's Edition.
\end{abstract}

\title{
REFERENCES
}

Agrippa of Nettesheim, Henry Cornelius. 2017. The Three Books of Occult Philosophy. Donald Tyson (ed.). Woodbury: Llewellyn Publications.

The Art of C.G. Jung. 2019. Edited by the Foundation of the Works of C.G. Jung. Ulrich Hoerni, Thomas Fischer, Bettina Kaufmann. Translated from German by Paul David Young and Christopher John Murray. New York and London: W.W. Norton \& Company.

Baynes Janson, Diana.2003. Jung's Apprentice. A Biography of Helton Godwin Baynes. Einsiedeln: Daimon Verlag.

Berthelot, Marcellin. 1887. Collection des Anciens Alchemistes Grecs, I. Paris: Georges Steinheil.

Bishop, Paul. 2008. Analytical Psychology and German Classical Aesthetics. Goethe, Schiller, and Jung. Vol. 1. The Development of the Personality. London and New York: Routledge Taylor and Francis Group.

Éveno, Bertrand. 2015. 'Jung's "Multicolored Arabesques": Their Renderings and Intentions in the Pictorial Vocabulary of The Red Book.' Psychological Perspectives 58, 1:5-33.

Fischer, Thomas and Bettina Kaufmann. 2019. 'C.G. Jung and Modern Art.' In The Art of C.G. Jung. Edited by the Foundation of the Works of C.G. Jung. Ulrich Hoerni, Thomas Fischer, Bettina Kaufmann. Translated from German by Paul David Young and Christopher John Murray. New York and London: W.W. Norton \& Company:19-31.

Goethe, Johann Wolfgang von [1810] 2016. Zur Farbenlehre. Berlin: GmbH \& Co.

. [1840] 2006. Theory of Colours. Trans. with notes by Charles Lock Eastlake (Mineola, New York: Dover Publications, Inc.). 
Greene, Liz. 2018a. The Astrological World of Jung's Liber Novus. London: Routledge.

2018b. Jung's Studies in Astrology. Prophecy, Magic, and the Qualities of Time. London: Routledge.

Guinon, Georges and Woltke, Sophie. 1891. 'De l'influence des excitations des organes des sens sur les hallucinations de la phase passionnelle de l'attaque hysterique.' Archives de Neurologie 21 (63):346-65.

Harms, Donald. 2011. 'Geometry of Jung's Systema Munditotius.' Jung Journal: Cultural \& Psyche 5 (3):145-159.

-2016. Geometric Wholeness of the Self. The Mandala as a Psychological and Spiritual Representationn of the Self. Napa (California): Donald Harms.

Hoch, Medea. 2019. 'C.G. Jung's Concepts of Color in the Context of Modern Art.' In The Art of C.G. Jung. Edited by the Foundation of the Works of C.G. Jung. Ulrich Hoerni, Thomas Fischer, Bettina Kaufmann. Translated from German by Paul David Young and Christopher John Murray. New York and London: W.W. Norton \& Company:33-49.

Hoerni, Ulirch.2019. 'Images from the Unconscious: An Introduction to the Visual Works of C.G. Jung.' In The Art of C.G. Jung. Edited by the Foundation of the Works of C.G. Jung. Ulrich Hoerni, Thomas Fischer, Bettina Kaufmann. Translated from German by Paul David Young and Christopher John Murray. New York and London: W.W. Norton \& Company:10-16.

Hyde, Maggie. 1992. Jung and Astrology. London: The Aquarian Press.

Jeromson, Barry. 2005/2006. 'Systema Munditotius and Seven Sermons: Symbolic Collaborators in Jung's Confrontation with the Dead.' Jung History 1 (2):6-10.

Jung, Carl Gustav.1902. On the Psychology of So-Called Occult Phenomena. Collected Works of C. G. Jung. vol.1: §1-149.

1909. The Association Method. Collected Works of C. G. Jung. vol. 2: $\S 939-998$.

. [1912] 1991. The Psychology of the Unconscious. Translated by Beatrice M. Hinkle. London: Moffat, Yard and Company. Reprinted with an introduction by William McGuire. London: Routledge.

1913. A Contribution to the Study of Psychological Types. Collected Works of C. G. Jung. vol. 6: §858-882. 
- 1916a. 'Introjection and Projection', unpublished discussion of the Association for Analytical Psychology, October 1916.

-.[1916b] 1917. 'Conception of the Unconscious.' In Collected Papers On Analytical Psychology. Constance E. Long (ed.). $2^{\text {nd }}$ edition. New York: Moffat, Yard.

-1917. 'The Psychology of the Unconscious Processes.' In Collected Papers On Analytical Psychology. Constance E. Long (ed.). $2^{\text {nd }}$ edition. New York: Moffat, Yard.

- 1921a. Psychologische Typen. $5^{\text {th }}$ and $6^{\text {th }}$ edition 1930. Zürich: Rascher \& Cie.

- [1921b] 1971. Psychological Types. Collected Works of C. G. Jung. vol. 6.

- 1923. Psychological Types or The Psychology of Individuation. trans. H.G. Baynes. London: Kegan Paul.

- [1929] 1938. 'Commentary on "The Secret of the Golden Flower"'. Collected Works of C. G. Jung. vol. 13: §1-84.

- [1931a]. Archaic Man. Collected Works of C.G. Jung. vol.10: $\S 104-147$.

1931b. The Secret of the Golden Flower. Trans. Richard Wilhelm. Commentary by C.G. Jung. London: Kegan Paul, Trench, Trubner \& Co.

- [1934] 1950. A Study in the Process of Individuation. Collected Works of C. G. Jung. vol. 9, 1: §525-626.

- 1936. 'Traumsymbole des Individuationsprozesses, ' Eranos-Jahrbuch 1935 (Zurich: Rhein-Verlag):13-133.

1937. Bericht über die Berliner Vortrage von Prof. Dr.

C. G. Jung. 28/29 September 1937 (Ausgearbeited von Frau Marianne Stark, Berlin). Unpublished typescript.

1938. Psychology and Religion. New Haven: Yale University Press.

.1939. 'Dream Symbols of the Process of Individuation.'

In The Integration of the Personality. Translated by Stanley

M. Dell. New York: Farrar \& Rinehart, Inc.

1951. Aion. Collected Works of C. G. Jung. vol. 9, 2. vol. 5 .

1952. Symbols of Transformation. Collected Works of C.G. Jung. 1953. Psychology and Alchemy. Collected Works of C. G. Jung. 
vol. 12 .

1954. On the Nature of the Psyche. Collected Works of C. G. Jung. vol. 8: §159-442. vol. 14.

1955. Mysterium Coniunctionis. Collected Works of C. G. Jung. 1958. Psychology and Religion. Collected Works of C. G. Jung vol. 11.

1959. Modern Psychology. Notes on Lectures given at the Eidgenössiches Technische Hochschule, Zürich. 3, 'Eastern Texts'. $2^{\text {nd }}$ Edition. Privately published.

1973. Letters, vol. 1. Selected and edited by Gerhard Adler in collaboration with Aniela Jaffé. London: Routledge \& Kegan Paul. 1984. Dream Analysis: notes of the seminar given in 1928-30. William McGuire (ed.). London: Routledge \& Kegan Paul. .[1989a] 2012. Introduction to Jungian Psychology: Notes of the Seminar on Analytical Psychology Given in 1925. Ed. William McGuire (ed.). Revised edition. Sonu Shamdasani (ed.) Princeton: Princeton University Press.

1989b. Nietzsche's Zarathustra: notes of the Seminar given in 1934-39. 2 vols. James L. Jarrett (ed). London: Routledge.

1997: Visions: notes of the seminar given in 1930-1934. 2 vols. C. Douglas (ed.). Princeton: Princeton University Press.

.2008. Children's Dreams. Notes from the Seminar Given in 1936-1940. Lorenz Jung and Maria Mayer-Grass (eds.). Ernst Falzeder (trans.). Princeton: Princeton University Press. 2009a. The Red Book: Liber Novus. Sonu Shamdasani (ed.). Mark Kyburz, John Peck, and Sonu Shamdasani (trans.). New York/London: W. W. Norton \& Company.

. 2009b. The Red Book: Liber Novus. A Reader's Edition. Sonu Shamdasani (ed.). Mark Kyburz, John Peck, and Sonu Shamdasani (trans.). New York/London: W. W. Norton \& Company.

. 2019a. Dream Symbols of the Individuation Process. Notes of C.G. Jung's Seminars on Wolfgang Pauli's Dreams. Suzanne Gieser (ed.). Princeton and Oxford: Princeton University Press.

-2019b. History of Modern Psychology. Lectures delivered at ETH Zurich. Volume 1. 1933-34. Ernst Falzeder (ed.). Princeton and 
Oxford: Princeton University Press.

Jung, Carl Gustav/Jaffé, Aniela.1963. Memories, Dreams, Reflections. Clara and Richard Winston (trans.). London: Collins and Routledge \& Kegan Paul.

Jung, Carl Gustav/Members of the Class. 1923. Notes on the Seminar in Analytical Psychology conducted by Dr. C.G. Jung. Polzeath, England, July 14- July 27, 1923. Unpublished typescript.

Kingsley, Peter. 2018. Catafalque: Carl Jung and the End of Humanity. 2 vols. London: Catafalque Press.

Laughlin, Kiley. 2016. Treasure Hunting. A Hermeneutical Inquiry into the Final Painting of Liber Novus. PhD disss. Pacifica Graduate Institute, California. PDF accessed via www.academia.edu in 2019.

Mellick, Jill. 2018. The Red Book Hours, Discovering C.G. Jung's Art Mediums and Creative Process. Zurich: Scheidegger \& Spiess.

2019. 'Matter and Method in The Red Book: Selected findings', In The Art of C.G. Jung. Edited by the Foundation of the Works of C.G. Jung. Ulrich Hoerni, Thomas Fischer, Bettina Kaufmann. Translated from German by Paul David Young and Christopher John Murray. New York and London: W.W. Norton \& Company:217-232.

Owens, Lance. 2011. 'Jung and Aion: Time, Vision, and a Wayfaring Man.' Psychological Perspectives 54 (3): 253-289.

Portal, Frédéric. 1837 Des Couleurs symboliques dans l'Antiquité, Le Moyen Age et les Temps Modernes. Paris: Treuttel et Würtz.

Protocols of the interviews conducted by Aniela Jaffé with C.G. Jung for Memories, Dreams, Reflections. Library of Congress, Washington, DC.

Reeves, Marjorie. [1976] 1999. Joachim of Fiore \& The Prophetic Future. London: SPCK. $2^{\text {nd }}$ ed. Gloucester: Sutton Publishing Ltd.

Rossi, Safron. 2015. 'Saturn in C.G. Jung's "Liber Primus", Jung Journal 20159 (1):38-57.

Shamdasani, Sonu.2012. C.G. Jung A Biography in Books. New York/ London: W.W. Norton \& Company.

Shamdasani, Sonu. 2018: 'Expressions symboliques: Jung, Dada, le mandala et l'art de la folie,' in Jung et l'élan créateur. Xe Colloques de Bruxelles, Brussels, Esperluète/L'Arbre Soleil: 269-308.

Sherry, Jay. 2010. A Pictorial Guide to The Red Book. Accessed via https://aras.org/sites/default/files/docs/00033Sherry.pdf 
Silberer, Herbert. 1914. Probleme der Mystik und ihre Symbolik. Vienna: Heller.

Zervas, Diane Finiello. 2019a. 'Intimations of the Self.' In The Art of C.G. Jung. Edited by the Foundation of the Works of C.G. Jung. Ulrich Hoerni, Thomas Fischer, Bettina Kaufmann. Translated from German by Paul David Young and Christopher John Murray. New York and London: W.W. Norton \& Company:179-210. 2019b. 'Philemon, Ka, and Creative Fantasy: The Formation of the Reconciling Symbol in Jung's Visual Work, 1919-1923.' Phanês. Journal for Jung History 2: 59-103. 
APPENDIX

COLOURS IN THE RED BOOK

1. Word Frequency/Colours in Liber Novus text

Main Characters/Objects

frequency
Colours and Values

frequency

Dark/ness 246

Light/ness: $\quad 219$

Christ $\quad \pm 192$

Devil 159

Blood/y: $\quad 115$

Black/ness $\quad 103$

Philemon $\quad 78$

Abraxas $\quad 73$

Red/ Crimson 75

White 66

Bird $\quad 60$

Chaos 49

$\begin{array}{lr}\text { Gold } & 46 \\ \text { Green } & 44 \\ \text { Blue } & 22 \\ \text { Yellow } & 11 \\ \text { Sillver } & 6 \\ \text { Orange } & 0 \\ \text { Brown } & 0 \\ \text { Purple/viola } & 0\end{array}$

PHANÊS

Vol $3 \cdot 2020$ 


\section{Historiated Initials, Chapter Numbers and Titles, Dialogue Interlocutors in the Red Book}

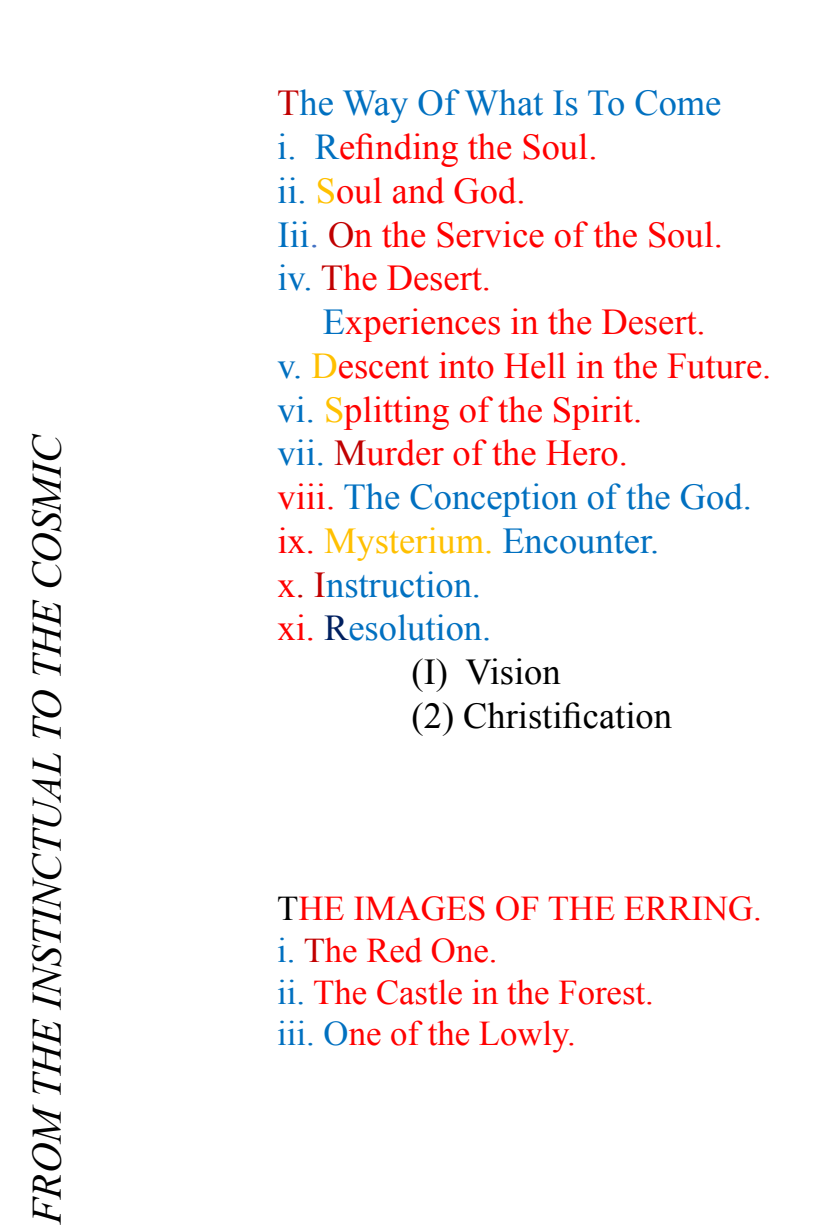

\section{LIBER PRIMUS}

\begin{tabular}{|c|c|c|}
\hline $\begin{array}{l}\text { Jung's I } \\
\text { Jung's I }\end{array}$ & Spirit of the Times & Spirit of the Depths \\
\hline Jung's I & Spirit of the Times & Spirit of the Depths \\
\hline Jung's I & Soul & Spirit of the Depths \\
\hline Jung's I & Soul & \\
\hline Jung's I & Soul & \\
\hline Jung's I & Many voices & \\
\hline Jung's I & Spirit of the Depths & Soul \\
\hline Jung's I & Spirit of the Depths & \\
\hline Jung's I & Spirit of the Depths & \\
\hline Jung's I & Elijah & Salome \\
\hline Jung's I & Elijah & Salome \\
\hline ung's & Mime & \\
\hline g's I & Elijah & Salome \\
\hline
\end{tabular}

\section{LIBER SECUNDUS}

$\begin{array}{ll}\text { Jung's I } & \text { The Red One } \\ \text { Jung's I } & \text { Scholar She (Scholar's Daughter) } \\ \text { Jung's I } & \text { He (One of the Lowly) }\end{array}$




\begin{tabular}{|c|c|c|c|}
\hline iv. The Anchorite. dies.i. & Jung's I & Anchorite & \\
\hline v. dies ii. & Jung's I & Anchorite (Am & onius) \\
\hline vi. Death. Dialogue: direct & Jung's I & Death & \\
\hline vii.Remains of Earlier Temples. & Jung's I & Ammonius & The Red One \\
\hline viii.First Day. & Jung's I & Izdubar & \\
\hline ix. Second Day. & Jung's I & Izdubar & \\
\hline $\mathrm{x}$. The Incantations $\left[2^{\text {nd }}\right.$ layer $]$ & no dialogue & & \\
\hline xi. The Opening of the Egg & Jung's I & Izdubar & \\
\hline xii. Hell. & No dialogue & voice & \\
\hline xiii. The Sacrificial Murder. & Jung's I & She (Soul) & \\
\hline xiv. Divine Folly. & Jung's I & Librarian & \\
\hline xv. Nox secunda. & Jung's I & Cook Ezechiel & ofessor Superintendent \\
\hline xvi. Nox tertia. & Jung’s I/I & Soul & Someone/fool, Professor \\
\hline xvii. Nox quarta. & Jung's I & Soul Cook & Librarian \\
\hline xviii. The Three Prophecies. & Jung's I & Soul & \\
\hline xix. The Gift of Magic. & Jung's I & Soul & \\
\hline xx. The Way of the Cross. & no dialogue & White bird & \\
\hline xxi. The Magician. & & & \\
\hline$\{1\}$ & Jung’s I & $\Phi \mathrm{I} \Lambda \mathrm{HM} \Omega \mathrm{N}$ & \\
\hline$\{2\}$ & Jung's I & Serpent (Soul) & \\
\hline & Jung's I & Serpent & \\
\hline$\{3\}$ & Jung's I & Serpent (Soul) & Satan \\
\hline $2^{\text {nd }}$ layer & Jung’s I & Cabiri & \\
\hline & Jung's I & Cabiri & \\
\hline$\{4\}$ & Jung's I & He (The Hange & Man) \\
\hline$\{5\}$ & Jung's I & Serpent Elijah & alome \\
\hline$\{6\}$ & Jung's I & Serpent Bird S & ome Raven Satan \\
\hline
\end{tabular}

